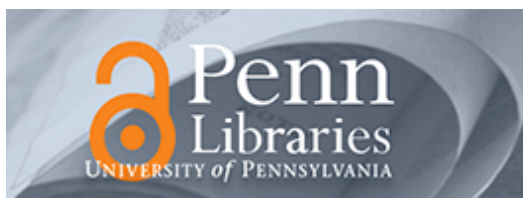

University of Pennsylvania ScholarlyCommons

Wharton Pension Research Council Working

Papers

Wharton Pension Research Council

$1-1-2005$

\title{
Understanding the Defined Benefit versus Defined Contribution Choice
}

Tongxuan (Stella) Yang

The Wharton School, University of Pennsylvania, TONGXUAN@WHARTON.UPENN.EDU

Follow this and additional works at: https://repository.upenn.edu/prc_papers

Part of the Economics Commons

Yang, Tongxuan (Stella), "Understanding the Defined Benefit versus Defined Contribution Choice" (2005). Wharton Pension Research Council Working Papers. 378.

https://repository.upenn.edu/prc_papers/378

This paper is posted at ScholarlyCommons. https://repository.upenn.edu/prc_papers/378

For more information, please contact repository@pobox.upenn.edu. 


\title{
Understanding the Defined Benefit versus Defined Contribution Choice
}

\begin{abstract}
Defined benefit (DB) plans and defined contribution (DC) plans are the two main types of retirement pensions sponsored by US employers. This paper explores the choices made by employees in a non-profit firm when offered the option of switching from a DB to a DC plan. Overall, half of the employees switched into the DC plan and half stayed with the DB. We find that both demographic and economic factors affected an employee's plan switch decisions. We also find that the default option - by making no active election an employee remained in the old DB plan - had an important impact on some employees' retirement savings. Surprisingly, half of the employees under age of 40 who could potentially benefit more from the DC plan defaulted to the DB plan, and the DB defaulters were more similar to the DC switchers than DB choosers. According to the employer's calculation, altogether the defaulted employees with positive opportunity costs have forgone \$7M, or 37 percent of their annual salary. Among those who switched to the DC plan, the contribution rates were affected by the DC plan match formula, the employee's age, salary, and other saving. Given the actual behavior of those who switched, there was virtually no change in employer pension expenses after the switch.
\end{abstract}

\section{Disciplines}

Economics 


\title{
Understanding the Defined Benefit versus Defined Contribution Choice
}

\author{
Tongxuan (Stella) Yang
}

PRC WP 2005-4

\section{Pension Research Council Working Paper}

\author{
Pension Research Council \\ The Wharton School, University of Pennsylvania \\ 3620 Locust Walk, 3000 SH-DH \\ Philadelphia, PA 19104-6302
}

Tel: 215.898.7620 Fax: 215.573.3418

Email: prc@wharton.upenn.edu

http://www.pensionresearchcouncil.org

Pension Research Council Working Papers are intended to make research findings available to other researchers in preliminary form, to encourage discussion and suggestions for revision before final publication. Opinions are solely those of the authors. Funding for this research was provided by the Pension Research Council and the Insurance and Risk Management Department at the Wharton School of the University of Pennsylvania. The author is grateful for comments from Leny Bader, Dominic Disandro, Eileen Founds, and Jack Heuer. The author also acknowledges helpful suggestions from Andrew Au, Neil Doherty, Michael Heller, Robert Inman, Marie-Eve Lachance, Brigitte Madrian, David McCarthy, Olivia S. Mitchell, Alex Muermann, Stephen Shore, and Matthew White. Any remaining errors are the author's responsibility. (C2005 Pension Research Council of the Wharton School of the University of Pennsylvania. All Rights Reserved. 


\title{
Understanding the Defined Benefit versus Defined Contribution Choice
}

\author{
Tongxuan (Stella) Yang
}

\begin{abstract}
$\underline{\text { Abstract }}$
Defined benefit (DB) plans and defined contribution (DC) plans are the two main types of retirement pensions sponsored by US employers. This paper explores the choices made by employees in a non-profit firm when offered the option of switching from a DB to a DC plan. Overall, half of the employees switched into the DC plan and half stayed with the DB. We find that both demographic and economic factors affected an employee's plan switch decisions. We also find that the default option - by making no active election an employee remained in the old DB plan - had an important impact on some employees' retirement savings. Surprisingly, half of the employees under age of 40 who could potentially benefit more from the DC plan defaulted to the DB plan, and the DB defaulters were more similar to the DC switchers than DB choosers. According to the employer's calculation, altogether the defaulted employees with positive opportunity costs have forgone $\$ 7 \mathrm{M}$, or 37 percent of their annual salary. Among those who switched to the DC plan, the contribution rates were affected by the DC plan match formula, the employee's age, salary, and other saving. Given the actual behavior of those who switched, there was virtually no change in employer pension expenses after the switch.
\end{abstract}




\title{
Understanding the Defined Benefit versus Defined Contribution Choice
}

\author{
Tongxuan (Stella) Yang
}

Since the 1980s, defined contribution (DC) plans have become critically important mechanisms for retirement provision. ${ }^{1}$ There are several explanations for the trend toward DC plans. ${ }^{2}$ First, some employers are reluctant to launch new defined benefit (DB) plans because of relatively high and rising expenses. Second, DC plans have flourished due to their appeal to both employers and employees. ${ }^{3}$ Third, some employers have felt the need to shift risk from the firms to employees. Although DC plans have many advantages compared to DB plans, this does not necessarily mean that DC plans are superior for everyone. ${ }^{4}$ The major advantage of DB plans is their potential to provide a stable income replacement rate, with capital market and longevity risk borne by employers. DB plans might be a good choice for stable employees, those who are less financially sophisticated, and those who are unwilling to take investment risk.

Because theory fails to show either plan type's superiority, we turn to empirical evidence to ascertain how employees make one of their most important financial decisions — choosing a retirement plan — when offered a one-time option to switch from a DB to a DC pension plan. We are also interested in the "default effect", i.e., if an employee did not affirmatively elect any plan by a certain date, he would remain in the old DB plan. In this paper, we explore several questions using a rich, unique dataset provided by a large non-profit organization. First, which employees switched from the DB to the DC plan, and how did they compare to those who did not? Second, were the defaulters different from those who actively selected the DB plan? How much money was potentially given up as a result of not switching to the DC plan? Why did so many young employees default to the DB plan when they potentially could obtain higher benefit 
from the DB plan? Third, how did the DC switchers determine their contribution rates to the new DC plan? Fourth, how did employee choices influence the employer's pension expenses?

The results show that half of the employees switched into the DC plan and half stayed with the DB plan. We find that both demographic and economic factors affected an employee's plan switch decisions. Female, white, higher-income, non-unionized, and longer-service employees were more likely to choose the DC plan. Employees also favored the DC plan if they had past experience with DC-type retirement saving plans and if it was easy for the projected DC benefit to catch up to the projected DB benefit.

The default option had an important impact on some employees' plan choice and retirement savings. Surprisingly, about half of the employees under the age of 40 who could potentially benefit more from the DC plan defaulted to the DB plan, and the DB defaulters were more similar to the DC switchers than DB choosers. According to the employer's calculation, altogether the defaulted employees with positive opportunity costs have given up $\$ 7 \mathrm{M}$, or 40 percent of their annual salary. Among those who switched into the DC plan, older, higherincome, non-African American, and employees with previous DC saving tended to have higher contribution rates. Given the actual behavior of those who switched, there was virtually no change in employer pension expenses after the switch.

This paper contributes to the existing literature in several ways. Not only do we examine how demographic factors affect employee retirement plan choices, but we also explore the employee responses to the economic incentives characterized by the internal rate of return and projected benefit difference between the DC and the DB plans. We find that, in general, an employee is more likely to switch to the DC plan if it is easier for his DC benefits to catch up to the old DB benefits. Furthermore, this paper explores a new facet of passive choices in 
retirement savings: how default options influence pension plan choice. We find that many employees, especially the young, made passive choices and in doing so gave up a large amount of pension benefits. Last but not least, we investigate the contribution decisions of switched employees, and the actual influence of employee choices on employer pension expenses, two topics little examined in previous research.

This research may also shed some light on possible Social Security reform. If part of the Social Security payroll tax could be deposited into a personal account, ${ }^{5}$ policymakers should know who might be more likely to set up such an individual account, how a default option might influence their decisions, and what determines individuals' contribution rates. This paper could help answer these questions.

In what follows, first, we describe previous research on the choice between DB and DC plans. Next we summarize the plan switch option offered by the large non-profit organization. Then we construct empirical models to explore how the employees made their decisions and present the corresponding empirical results. Finally, we conclude and discuss policy implications.

\section{Previous Studies on Employee Plan Choices}

Before reviewing the literature, it is helpful to outline the features of DB and DC plans. A DB plan rewards long service and pays a benefit that depends on final salary. Accordingly, a DB plan participant faces job change risk and employer default risk. If an employee leaves his employer prior to retirement, the DB benefit is usually frozen without any future indexation. Consequently, when the benefit is sought at the time of retirement, it will have been heavily eroded by inflation. This problem is serious for young employees, both because the backloading 
feature of the DB plan gives them low benefits at leaving, and because of the long time before retirement. It is also possible that a bankrupted firm may default on its DB pension benefit promises. ${ }^{6}$ By contrast, in a DC plan, the employer stipulates contribution amounts rather than benefit formulas. Consequently, a participant's risk in this case comes from the investment return of employee accounts. After the contribution rate has been decided, the DC accumulation depends heavily on the investment performance of the employee's total portfolio. Termination does not threaten DC participants particularly, because DC participants can always rollover their account into an IRA (or to a new employer's DC plan); consequently, the money can continue to accrue investment returns.

DC plans became popular in the United States after the passage of the Revenue Act of 1978; thereafter, increasing numbers of employers redesigned their retirement offerings by moving to DC plans. Some employers chose to supplement their old DB plans with new DC plans, usually contributory with an employer match. In other cases, employers let their employees choose between the old DB plan and a new DC plan. This choice was often given to the new hires, ${ }^{7}$ but some employers, like the one in this paper, allowed current employees to switch plans. ${ }^{8}$

Several theoretical studies explore the tradeoffs between DB and DC plans as well as participants' optimal selections (See Table 1). Bodie, Marcus, and Merton (1988) employ a three-period model to explore the influence of wage and interest rate uncertainty on DB and DC plans. By maximizing the utility of a representative worker subject to the constraint that both DB and DC plans have equal costs to the firm, they conclude that DB plans are not dominated by DC plans, since a DB plan offers workers a stable replacement rate of final income and some degree of insurance against real wage risk. DC plans also possess some advantages over DB plans, 
namely the predictability of the value of pension wealth, the ability to invest in inflation-hedged portfolios rather than nominal DB annuities, and (possibly) a fully-funded promise. McCarthy (2003) examines the value of a DB plan using a multi-period analysis, in which he incorporates wage uncertainty, market volatility, and mortality risk, allowing investment choice to change dynamically and endogenously. His paper suggests that wage-indexed claims offered by DB plans are more valuable when the employees are old, when equity markets provide low expected returns or are highly variable, and when annuity markets are inefficient. Childs et al. (2002) examine optimal retirement plan choices between DB and DC plans using a real options framework, taking into account employees' option to change employers in the future. The authors model an employee's current salary as well as a best alternative salary from changing employers, and they treat these two salaries as following a separate but possibly correlated diffusion process. The representative employee in this model chooses between a DB or DC plan using backward induction, by maximizing the sum of the present value of his remaining lifetime salary plus the present value of expected benefits received from the retirement plan at each node of a trinomial tree, a decision tree built from the drift and variance of the ratio of the current salary to the best alternative salary. Numerically simulating three hypothetical workers age 25 , 40, and 55, the paper finds that, for reasonable parameter values, DC plans are preferred by young employees and employees with higher turnover rates, higher risk aversion, and higher employer contribution rates. Employees with more years of service and higher accrued DB benefits are more likely to stay in the old DB plan.

\section{Table 1 here}

To summarize, existing theoretical studies predict several hypotheses for us to test in our empirical analysis. First, because the fact that DC plans can better hedge job change risk, 
employees more likely to change jobs prefer DC plans. Second, the backloading feature of DB plans makes employees with more service and higher accrued benefits prefer DB plans. Third, young employees prefer DC plans because of their higher job change probabilities and the DC plan's capability to help them diversify total portfolio risk when most of their assets are in human capital.

There are only a few empirical studies on employee plan choices. One, by Papke (2004), explores the DB and DC plan choices made by corrections workers covered by the Michigan State Employee Retirement System. The paper finds a relatively low switch rate among correction workers: only 1.6 percent, lower than the 5.5 percent for all Michigan public employees. Papke (2004) finds that age and salary were not the determinants of plan switch decision; however, plan vesting, which enabled a worker to transfer the present value of accrued DB benefits to the DC plan, had a significantly positive influence on the switch decision. Brown et al. (2004) seek to answer the question of why only one-third of existing employees in the Superannuation Scheme for Australian Universities switched to a DC from a DB plan. Based on 152 responses to 620 surveys, they conclude that "risk transfer costs" deterred employees from switching to the DC plan. The risk transfer costs referred to "any costs associated with risks that transfer from the employer to the employee when employees shift from a defined benefit to an accumulation plan [DC plan], and any newly arising risks borne by employees when they transfer" (P. 6). Limited by their data, neither study explores how the employees responded to the economic incentives, for example, the projected benefit amounts. Nor do they investigate the influences of the default effect as well as the switched employees' saving behavior.

Two other related papers, by Clark, Harper, and Pitts (1997) and Clark, Ghent, and McDermed (2003), evaluate how newly hired North Carolina State University faculty chose 
between the state public DB plan and several DC plans. Their surveys of the faculty hired between 1971-1995 and 1983-2001 show that older, female, and black newly hired faculty were more likely to select the DB plan. The papers also find that mobility expectations, labor market conditions, faculty rank, and type of appointment all had an impact on plan choice. Their work differs from our research since we focus on the plan choices of current employees offered a onetime opportunity to switch from a DB to a DC plan, not on the plan choices of new hires.

A handful of other studies describe existing employees' plan choices, but none of them links these choices to employee characteristics. A consistent finding is that relatively few people seem to switch to DC plans: for instance, fewer than 10 percent of Florida state employees chose the DC plan when given the choice in 2001, while over 80 percent defaulted to the old DB plan (Feinberg, 2004). ${ }^{9}$ Similarly, only 10 percent of existing employees at Florida Daytona Beach Community College facing a DC/DB election selected the DC plan, while 80 percent of new employees elected the DB option (Trager, Francis, and SigRist, 2001). In a large electronics company, only one-third of employees chose to switch to a DC plan when the employer offered a DB/DC choice (Rappaport, 2004). A large health care employer who offered the option to switch to a new DC plan found that only 20 percent of employees took the option, while the rest either selected or defaulted to the DB plan (Rappaport 2004). These studies paint a general picture of how employees behave when offered a switch, but they do not reveal the determinants of plan choices, nor do they indicate switched employees' saving rates.

This paper contributes to the literature in several ways. Unlike previous studies, we not only examine how demographic factors affect employee retirement plan choices, but we also explore the employee responses to the economic incentives characterized by the internal rate of return and projected benefit difference between the DC and the DB plans. Furthermore, this 
paper explores a new facet of passive choices in retirement savings: how default options influence pension plan choice, how much money was given up by the defaulted employees, and why so many young employees defaulted to the DB plan. Finally, we investigate the contribution decisions of switched employees, and the actual influence of employee choices on employer pension expenses, two topics little examined in previous research.

\section{The Plan Switch and the Data}

Prior to the year 2000, the firm we studied offered a DB pension to its weekly paid, fulltime employees. The annual benefit amount was specified by the following formula:

\section{DB Benefit $=1.25 \% \cdot$ Final Average Pay $・$ Years of Service,}

where the final average pay (FAP) represents the average of an employee's highest five years of earnings in the last 10 years of work while in the DB plan. The DB plan was non-contributory, and vesting occurred after the participant completed at least 1000 hours of service per year for five years. ${ }^{10}$ The DB participants were also allowed to contribute to a Supplemental Retirement Annuity (SRA), a DC-type pre-tax retirement saving account.

In the late 1990s, some employees contended that the DB plan offered a potentially lower benefit than that provided by a DC plan. ${ }^{11}$ For example, the DB plan did not have immediate vesting and portability, nor did it offer employees the chance to make their own investment decisions. Nevertheless, the DB plan was attractive since it did not require employee contributions, while the DC plan did require direct employee contributions in order to be eligible for the employer match. Of course, from an employer's perspective, a DC plan has its own appeal. A DC plan is easier to communicate and administer, while its expenses are more predictable than those of the DB plan. Moreover, offering a DC plan to all might help the 
employer pass the legally required non-discrimination tests, which require qualified retirement plans not to discriminate in favor of highly compensated employees (i.e., in the year 2000, anyone earning over $\$ 85,000)$. For all these reasons, the decision to redesign the retirement plans was seen as accommodating both employee and employer interests.

In March of 2000, the firm offered a one-time opportunity to this group of employees to switch from the old DB plan to a new DC plan. The DC setup had three layers of contributions. First, the firm provided everyone who selected the DC plan with a "basic" age-based contribution, which did not require any employee contribution. This was worth 1 percent of pay for those younger than age 30, 3 percent of pay for those age 30 to 39 , and 4 percent of pay for those age 40 and over. This contribution would begin after one year of service. Second, employees were also permitted to make voluntary contributions up to the maximum allowable contribution amount under federal law and regulations. ${ }^{12}$ In 2000 , the annual employee contributions to the DC-type plans generally could not exceed the lesser of $\$ 10,500$ or 20 percent of salary. All employee contributions were vested immediately. Third, if an employee made a voluntary contribution to the DC plan, the employer would provide a dollar-for-dollar match up to 5 percent of salary. Employees could begin to contribute immediately at hire, while the employer match would begin after a year of service.

The switch option given to the DB participants was one-time and irrevocable, with all decisions required to be made before June 1, 2000. In March of that year, the Human Resources Department prepared a Plan Decision Kit for all eligible employees, which included the following components:

- Retirement Plan Decision Guide - a description of the important features of both plans and instructions on how to make an election. 
- Personalized Illustration of Annual Retirement Benefits - a personalized benefit sheet that provided an estimated comparison of a given employee's projected benefits from the DB and DC plans. These computations assumed the employee would stay at the firm for another 10, 15, and 20 years, or until age 65 (See Appendix 1).

- Mutual Fund Provider's Enrollment Kits - two kits providing detailed information about DC plan investment options from two mutual fund companies.

- Special Retirement Plan Election Form - a form to be filled in and returned by each employee to show his plan decision.

- DC Plan Election Form - an additional form only for an employee who decided to switch to the DC plan.

- A prepaid envelope.

Besides the Plan Decision Kit, the employer provided additional services to assist employee decision making. In addition to reviewing the Personalized Illustration of Annual Retirement Benefits based on common assumptions for everybody, employees could access an online program to evaluate the effect of changing assumptions such as retirement age or investment returns. The Human Resources Department, with one of the mutual fund providers, also held several group and individual meetings to explain the DB and DC plan features and answer employee questions.

Every employee was required to complete the Special Retirement Plan Election Form and return it to the Human Resources Department no later than June 1, 2000. If the election form was not received by that date, the employee forfeited his one-time opportunity to join the DC plan and would remain in the DB plan, or in other words, he would default to the DB plan. In this event, his benefits would be decided by the DB formula at retirement. Employees who switched 
to the DC plan were asked to specify their contribution rates and asset allocation decisions; otherwise, the employer's basic contributions defaulted into the money market fund only, and additional employee contributions as well as the employer's match were set at zero. Switched employees' accrued, vested DB benefits were frozen as of June $1,2000 .{ }^{13}$

The dataset provided by the employer contains information on 3,535 employees eligible to make the plan switch. The file indicates each employee's plan decision, i.e., whether he chose to switch to the DC plan, elected to stay in the DB plan, or defaulted into the DB plan. For those who switched to the DC plan, we also know their contribution rates. Moreover, the dataset provides employee characteristics including age, salary, years of service with the employer, sex, education, ethnicity, bargaining unit, and division information (See Table 2).

\section{Table 2 and Figure 1 here}

Table 2 and Figure 1 show that about half of the 3,535 employees elected to switch to the DC plan, a switch rate higher than in any other study described in the literature to date. Of the 1,784 employees who remained in the DB plan, two-thirds of this group, or one-third of all employees, defaulted into the DB plan. Only 221 of those eligible (6 percent of all employees) actively selected the DB plan. ${ }^{14}$ Employee plan choices across age groups are shown in Figure 2, where we see that the switch rate is higher for employees in their 30s and 40s, but lower for employees older than 50 . The most surprising result comes from the group in their $20 \mathrm{~s}$, whose switch rate was only 40 percent, far below the employer's expectation of 80 percent. For the employees who switched into the DC plan, the average pre-tax contribution rate of all participants was 6 percent of salary.

A representative employee was 41 years old, with an annual salary of $\$ 28,000$ and 9 years of service with the employer. There were fewer males ( 40 percent) than females. Only 
about one-quarter had college degrees; some 44 percent had no college degree, and for the remaining 31 percent, education information was lacking. Regarding ethnicity, 46 percent of the employees were White, 35 percent were African-American, and 5 percent were NativeAmerican, Asian-American and Hispanic; for 14 percent ethnicity information was lacking. ${ }^{15}$ About a quarter of the employees were union members, and they belonged to 10 different bargaining units. On average, these employees had accrued a DB lifetime annuity worth about $\$ 3,060$ per year, which could be collected only at retirement. Athough each employee had the option of saving pre-tax salary through the Supplementary Retirement Annuity, only 18 percent actually had put any money into the SRA account; the average contribution rate was 6 percent among employees with positive contribution rates.

To examine the switch decision, we use projected benefit values calculated by the employer and provided to the participants in the Personalized Illustration of Annual Retirement Benefits in the Plan Decision Kit. The average DC and DB benefit difference was $\$ 3,290$ in annuity terms, assuming that the employee retired at the age of $65 .{ }^{16}$ In an unreported table, we find that younger employees would benefit more from the DC plan, since both their contribution and investment periods were much longer than for older employees. Consequently, with the above assumptions, their DC plan benefits had the potential to exceed the DB plan benefits. As age increased, the benefit difference decreased, both because the DC plan contribution and investment period was shorter, and because the back-loading feature of the DB plan made the DB benefit rise quickly. On average, if an employee was older than 45 , his projected DB benefits would be higher than his projected DC benefits. 


\section{Empirical Models and Results}

In what follows, we focus on how the employees chose between the DB and the DC plans at this non-profit firm. Specifically, we ask which employees switched from the DB to the DC plan, how they compared to those who did not, and whether employees who defaulted to the DB plan differed from those who actively chose the DB plan. Further, we ask what the opportunity costs were for the DB defaulters, especially those young defaulters, and what the potential reasons were for them to fall in to the default. Next, for those employees who switched to DC plan, we examine how they determined their contribution rates. Finally, we explore the pension expense changes for the employer as the result of switch behavior of the employees.

\subsection{Employee Plan Choice Behavior}

To explore who switched to the DC plan, we compare them to the employees staying in the DB plan. We test the hypotheses noted above regarding the relationship between plan type and employee age, service, and DB accumulations. In addition to these factors, we hypothesize that other economic factors, including projected benefit differences between the DC and DB plans, the Internal Rate of Return (IRR), ${ }^{17}$ salary and other saving, and demographic factors (including gender, education, and bargaining unit) influence plan selection outcomes. The projected benefits of the DB plan and projected benefits of the DC plan for each employee were adapted from the Personalized Illustration of Annual Retirement Benefits.

In particular, we hypothesize that an employee is more likely to switch to the DC plan if his projected DC plan benefit is higher than his projected DB plan benefit. Therefore, the projected benefit difference, (DC-DB), is predicted to have a positive influence on employees' switch decisions. We hypothesize that employees with a higher salary should also be more likely 
to switch to the DC plan, both because their liquidity constraints may not be very tight, and because a higher income might enable an individual to bear more risk by providing a cushion for bad DC portfolio returns. ${ }^{18}$ It is well recognized that women are more likely to have an interrupted employment and salary history than men because of family burdens. Conditional on pay, therefore, we hypothesize that women would prefer the DC over the DB plan, because the former would be seen as more portable and hence provide higher benefits to job changers. Education may proxy for financial literacy, since more years of education may expose people to more financial knowledge and help them understand investment risk. If so, we predict that more educated employees would be more likely to switch to the DC plan. In this firm, the DB-covered workers had an option to save pre-tax money in an SRA, a retirement saving vehicle with DC characteristics. It is possible that those who were investing in the SRA prior to 2000 would also better understand the DC choice, compared to those without SRA saving, and their familiarity with DC plans might make them more likely to switch to the DC plan. On the other hand, such employees might also want to diversify by holding both a DB and DC plan, so it is an empirical question as to how existing SRA saving influenced plan selection outcomes. Finally, we include bargaining unit to proxy for peer effects, whereby pension decisions might be influenced by colleagues with more contacts (Duflo and Saez, 2002).

Our first empirical model of the switch decision is therefore described as follows, with Prob (DC) set equal to 1 if the employee selected the DC plan and 0 otherwise:

$$
\text { Prob }\left(\text { DC }_{i}\right)=f\left(\text { EconomicFactors }_{i} \text {, DemographicFactors }_{i}\right)+e_{1} \text {. }
$$

Here, the vector Economic Factors includes the projected benefit difference (DC-DB), salary, the existence of SRA saving, and the amount of accrued DB benefits. The vector Demographic 
Factors includes the worker's age, sex, service, education, risk aversion, ethnicity, and bargaining unit.

Table 3 shows the empirical results. Column 1 reports salary and service years, while Column 2 contains only the accrued DB benefit and vested indicator to explore these variables' pure effects. The accrued DB benefit is a function of salary and service, equaling 1.25 percent times of the product of salary and service. We focus first on the economic factors. Salary is positively correlated with the switch to the DC plan; switched employees earned on average $\$ 29,000$ annually versus $\$ 27,000$ for the stayers. The positive link between salary and switch may come from the liquidity constraint and investment risk tolerance discussed above. Employees with an SRA account are more likely to switch to the DC plan. This may be because familiarity with a DC model enhanced its appeal, or it could be the result of the bull market over the 1990s, making employees feel more optimistic about DC plan savings. Consistent with our hypothesis, age is negatively and significantly linked to the switch decision, meaning that younger employees are more likely to switch to the DC plan. Service is negatively correlated with the switch decision, meaning that employees with fewer years of service are more likely to switch to the DC plan. This is because more years of service could entitle an employee to higher backloaded DB benefits, creating an incentive for the employee to stay with the DB plan (consistent with Childs et al., 2002). The negative relationship could also be due to employee self selection, i.e., employees with longer service could be most satisfied with their jobs and thus unlikely to leave the employer before retirement. Women and Whites are less likely to stay with the DB plan, and education has no separate effect. Interestingly, there is evidence that unionized employees are more likely to stay with the DB plan, which may stem from the peer effect reported in Duflo and Saez (2002). Column 2 shows the influence of accrued DB benefits and 
vesting. Consistent with Childs et al.(2002), employees with lower accrued DB benefits are more likely to switch to the DC plan. Vested employees are more likely to switch to the DC plan than the non-vested employees. ${ }^{19}$

\section{Table 3 here}

The projected benefit difference between the DC and DB plans at the age of 65, (DCDB) ${ }_{65},{ }^{20}$ also affects plan election, as shown in Column 3 of Table 3 . These projected benefit computations developed by the employee use a consistent set of assumptions for all workers, including 7 percent investment return, 3 percent wage increase, and age 65 retirement for each employee. Surprisingly, we find that the projected benefit difference has a negative influence on employee switch decisions, meaning that an employee is less likely to switch to the DC plan if he expected more benefits from the DC plan. This counter-intuitive finding suggests that some employees might not have made their plan switch decision based on the projected benefit differences supplied by the employer. We believe this counter-intuitive result might arise for several reasons. First, the benefit differences were computed by the employer at a specific future point (e.g., at retirement age 65). Nevertheless, workers might have non-zero turnover possibility every year; in fact, the firm's 1999 DB plan actuarial report assumed a 7.2 percent termination rate for employees in their 30s, 5.2 percent for those in their $40 \mathrm{~s}, 2.6$ percent for $50 \mathrm{~s}$, and 0.1 percent for 60s and above. Second, the projected benefits calculations assumed everyone vested in the DB plan, yet young employees with a higher probability of job termination might not vest. Consequently, the projected DB benefits would have been overestimated for some. Third, the plan sponsor assumed DC investment return of 7 percent, which might have differed from investment returns assumed by the employees in arriving at their plan switch decisions. ${ }^{21}$ 
To partially mitigate these problems, we next turn to an Internal Rate of Return (IRR) calculation to investigate how the IRR might have affected employee plan selection. Previous behavioral research suggests that people tend to regard what they think they already have as a reference point, given an alternative choice. ${ }^{22}$ Accordingly, an individual might not accept an alternative option unless it provided a benefit no less generous than the status quo. In our case, the DB benefit might have served as the benchmark for the DC plan, so an employee might have switched to the DC plan only if he believed that he had a low projected DB benefit benchmark. To allow for such a reference effect, we calculate an IRR for each employee, defined as the investment return that would equate projected DB and DC benefits. We then use this as a regressor in the above empirical model, replacing the benefit difference, to see how this IRR threshold influenced employee plan choices. Moreover, in calculating each IRR, we take into account each employee's vesting status as well as the probability that the employee might change jobs in the future. The fact that the DC plan is portable means that a terminated employee's benefit could be rolled over and reinvested, potentially protecting it from inflation; as a result, the projected DC benefit provided by the sponsor would be underestimated. Accordingly, when calculating IRRs, we incorporate the turnover rate reported in the employer's defined benefit plan annual actuarial report in 1999.

To solve for the IRR, we first note that the expected present value of the DB benefit expressed as a present value at the worker's current age is given by:

$$
E[P V(D B)]=\frac{1}{(1+r)^{65-a}} \sum_{t=a+1}^{65} \theta_{t} \cdot B_{t},
$$


where

$$
B_{t}= \begin{cases}1.25 \% \cdot \frac{1}{5}\left(\sum_{j=t-5}^{t-1} \text { Salary }_{a}(1+w)^{j-a}\right) \cdot \text { ServiceYears }_{t} \cdot A F_{65} & \text { if } t-a+s_{0} \geq 5 \\ 0 & \text { if } t-a+s_{0}<5\end{cases}
$$

and $a$ is the age in 2000; $t$ is the age at point of evaluation; $\theta_{t}$ represents the employee's expected turnover rate at age $t$ conditional on working at age $a$; $B_{t}$ is the annuity benefit that one has accrued if he leaves the firm at age $t ; s_{0}$ is the employee's years of service as of $2000 ; w$ is the expected wage growth rate of 3 percent; and ServiceYears $t_{t}$ is the employee's tenure as of age $t$. The Annuity Factor at age $65, A F_{65}$, is calculated from the probability of being alive at age $\mathrm{t}$, which is $m_{t}$, and the discount rate $r$ (at 7 percent), assuming everyone dies by age 110 as in the mortality table:

$$
A F_{65}=\sum_{t=65}^{110} \frac{m_{t}}{(1+r)^{t-65}} .
$$

The expected present value of the DC plan benefit flowing from the employer's contribution can be calculated as: ${ }^{23}$

$$
\begin{aligned}
E[P V(D C)]=\frac{1}{(1+r)^{65-a}} \sum_{t=a+1}^{65} \theta_{t} & \cdot\left[\sum_{j=a}^{t-1}\left(B C_{j}+M C_{j}\right) \cdot \text { Salary }_{a} \cdot(1+w)^{j-a} \cdot\left(1+I_{R R}\right)^{T-j}\right] \\
& +\frac{1}{(1+r)^{65-a}} D B_{-} \text {Accrued }_{a} \cdot A F_{65}
\end{aligned}
$$

where $\mathrm{BC}$ is the basic $\mathrm{DC}$ contribution by the employer, tied to the employee's age; $\mathrm{MC}$ is the employer's dollar-for-dollar match up to 5 percent of the employee's contribution; and $D B_{-}$Accrued $_{a}$ is the employee's accrued DB plan benefit given his current age. Note that in the DC plan policy there is no employer match if the employee's service is shorter than a year, so $B C_{j}=M C_{j}=0$ if $j-a+s_{0}<1$. 
The IRR can be calculated by equating projected DB and DC benefits:

$$
E[P V(D B)]=E[P V(D C)] .
$$

We predict that the lower the IRR, the more likely the employee will choose to switch to the DC plan.

On average, the IRR was around 9 percent for all employees, and the average IRR of switchers was much lower than that of stayers: 7 percent and 14 percent respectively. These numbers support our hypothesis that employees with lower IRRs were more likely to switch to the DC plan, since it would have been easier for them to meet and exceed the DB benchmark. This hypothesis is further supported by multivariate analysis controlling on economic and demographic factors. For example, Column 4 of Table 3 shows that the IRR is significantly negatively associated with an employee's switch decision. In other words, employees with lower IRR are more likely to switch to the DC plan.

In summary, we find that both the economic and the demographic factors influenced the switch decision. Employees with higher salary, less accrued benefits, and other DC plan saving are more likely to switch to the DC plan. Employees also select the DC plan if it is easy for them to catch up to the DB plan benefit, proxied by the internal rate of return. Yet using the employer's projected benefit difference between DC and DB plan, (DC-DB) ${ }_{65}$, produces counterintuitive results, probably because this variable does not reflect several important factors that could have influenced plan switch decisions. We also find that young, female, short-tenured, White, and non-unionized employees are more likely to switch to the DC plan. 


\subsection{The Default Effect}

We next explore whether employees actively electing the DB plan differed from those defaulting to the DB plan, what are the opportunity costs of defaulting, and why many young employees defaulted to the DB plan rather than switching to the DC plan.

\subsubsection{The Differences between DB Defaulters and DB Choosers}

When the company offered the new plan, it specified that any employee who did not inform the Human Resources Department of his plan choice prior to June 1, 2000 forfeited his one-time opportunity to join the DC plan and defaulted to the DB plan until terminating employment. Thus any employee who wanted to stay with the DB plan could end up in that position via two different routes: either by filling out the Special Retirement Plan Election Form and mailing it back to the Human Resources Department, or by doing nothing and defaulting into the DB plan.

We next evaluate whether the defaulters were different from those who made active decisions. The null hypothesis is:

$H_{0}$ : Employees who defaulted into the DB plan are similar to those who actively chose the $D B$ plan.

The following empirical model is employed to explore the differences between active DB electors and DB defaulters:

$$
\operatorname{Pr} \operatorname{ob}\left(\text { Default }_{i}\right)=f\left(\text { EconomicFactors }_{i}, \text { DemographicFactors }_{i}\right)+e_{2},
$$

where Default equals 1 if the employee defaulted to the DB plan and 0 if he actively elected the DB plan. The model is estimated using probit analysis. If the null hypothesis is accepted, the coefficients/partial effects should not be significant individually and jointly; however, if the two 
groups differ from each other, we will find the coefficients/partial effects jointly and individually significant. The EconomicFactors and DemographicFactors are the same as those we used above in the switch decision analysis.

Table 4 reports the comparisons between employees who actively elected the DB plan versus those who defaulted to the DB plan. Columns 1 and 2 in Table 4 show that many variables are statistically significantly different from 0 . For instance, younger, shorter-tenured, and male employees are more likely to default into the DB plan; compared to Whites, all other ethnic groups are more likely to default. Employees with SRA saving and higher accrued DB benefits are less likely to default to the DB plan, which seems to suggest that defaulting employees are less interested in retirement savings on the whole. Although there is a negative relationship between income and DB defaulting, the result is not statistically significant after controlling on other variables. The Wald Chi squares of both probit analyses are much higher than the critical value at the 1 percent level, meaning that the explanatory variables are jointly significant at the 1 percent level. In summary, the null hypothesis is rejected, meaning that at least some of the employees defaulting to the DB plan differ from those actively electing the DB plan.

\section{Table 4 here}

Column 3 shows how the projected benefit difference at age 65 , (DC-DB $)_{65}$, is associated with default behavior controlling on other economic and demographic variables. The result shows that the DB defaulters tended to have a higher projected benefit difference than did the DB choosers, indicating that the defaulters potentially could obtain higher benefits had they switched to the DC plan. One might argue that these projected benefits may not capture the actual influence of plan differences, since the calculation ignores vesting, turnover rates, and 
investment risk as mentioned above. In Column 4, we therefore take into account these factors using the IRR, and we find that the DB defaulters on average would benefit more from the DC plan: the IRRs of defaulters are lower than those of DB choosers, suggesting that it is easier for the defaulters' DC benefits to catch up to the DB plan benchmarks than it is for the DB choosers'. Hence, the results on both (DC-DB) 65 and IRR show that compared with the DB choosers, the DB defaulters would do better in a DC plan. Consistent with Column 1 and Column 2, we find males, non-Whites, and employees with other DC saving are more likely to default to the DB plan.

\subsubsection{The Similarities Between DB Choosers and DC Switchers}

We have found that the DB defaulters were not very similar to the DB choosers, which suggests that at least some employees defaulted to the DB plan for reasons different from those driving the DB choosers. In fact, if we go back to examine the variable descriptions in Table 2, it is surprising to find that the DB defaulters appear more similar to DC switchers than DB choosers. The average age of DB defaulters is 38 , closer to that of DC switchers at 40 than to that of DB choosers at 53 ; further, the average salary of DB defaulters is $\$ 26,100$, closer to that of DC switchers at $\$ 28,700$ than to that of DB choosers at $\$ 31,200$; the same pattern is also found for service years. Since age, salary, and service are the major determinants of projected DB and DC plan benefits, it appears that the DB defaulters are more similar to the DC switchers. On average, the projected benefit difference of DB defaulters is positive at $\$ 5,820$ (even higher than that of DC switchers at $\$ 2,680$ ), indicating that on average the DB defaulters would do better if they had switched to the DC plan. By contrast, the average projected benefit difference of DB choosers is negative at $-\$ 1,480$, meaning that on average the DB choosers would benefit 
more from remaining in the DB plan. The internal rate of return of the DB defaulters, at 10 percent, is closer to that of DC switchers at 7 percent, rather than that of DB choosers at 21 percent. Figure 3 shows the distribution of IRR for different groups of employees. Plan choices of both DB choosers and DC switchers are sensitive to the economic incentives in the direction consistent with our intuition; at each selected percentile point, the DB choosers have much higher IRRs than the DC switchers. When focusing on the DB defaulters, we see that their IRRs are obviously close to, yet a little bit lower than, those of DC switchers at most of the selected percentile points (except at the $90^{\text {th }}$ percentile point).

Figure 3 here

To test whether the DB defaulters are similar to the DC choosers, we next examine the predicted switch probabilities of each group. We first run a probit model on all active electors with the dependent variable set to 1 if the employee was a DC switcher and 0 if he was a DB chooser. Explanatory variables are the same as those in Column 1 of Tables 3 and 4 . Then, using the coefficients from the probit model, we predict the switch probabilities of all employees, including the active electors and the DB defaulters. As shown in Figure 4, the average predicted switch probability of DB defaulters, at 0.9 , is closer to that of DC switchers at 0.92 , and far from that of DB choosers at 0.69 . The same pattern can be found on the medians of the predicted switch probabilities. Hence, this analysis implies that if all the defaulters had been forced to make an active plan selection, many of them would have chosen the DC plan.

Figure 4 here 


\subsubsection{The Opportunity Cost of DB Defaulters}

Since the DB defaulters and DB choosers prove to be different from each other, at least some of those who could have benefited more from the DC plan gave up something for not picking the right plan. Accordingly, we next ask how large the opportunity cost is, i.e., how much money the defaulters gave up, by subtracting the present value of projected DB benefits from that of projected DC benefits. The equation we have in mind is:

$$
\text { OpportunityCost }_{i}=P V\left(\text { projected_DCBenefits }_{i}\right)-P V\left(\text { projected_DBBenefits }_{i}\right) \text {. }
$$

Using the employer's calculation of projected benefits, Panel A of Table 5 shows that the present value of the opportunity cost is estimated to be $\$ 2,700$ in lump sum per capita across all defaulting employees. Summing over all defaulters, the cost totals about $\$ 3$ million, or 9 percent of total salary. According to the formula above, the opportunity cost is positive if an employee's projected DC benefits are larger than his projected DB benefits, and negative otherwise. We next focus on the subset of DB defaulters who are employees with positive opportunity cost, i.e., those whose DC benefits are projected to be greater than their projected DB benefits. On average, we estimate that a typical member of this subset gave up a lump sum equivalent to $\$ 9,300$. All together, the DB defaulters with positive opportunity costs left unclaimed $\$ 7$ million, or 37 percent of their annual salary, as a result of not switching to the DC plan. Generally, younger employees gave up more than the older employees, partly because younger employees had the potential to benefit more from the DC plan because of their longer contribution and investment horizons. Table 5 shows that older employees were hurt less by defaulting to the DB plan. Panel B of Table 5 shows how the calculations vary if we take into account both the vesting rule and turnover rates. We find that the number of employees defaulting and the size of the opportunity cost are quite close to those in Panel A. 


\section{Table 5 here}

\subsubsection{Potential Explanations for the Defaulting Effects Young Employees}

Another look at Figure 2 shows a U-shaped default rate across different age groups, i.e., the default rate was higher for both very young employees in their 20 s and for old employees in their $60 \mathrm{~s}$, with low default rates for those in the middle. ${ }^{24}$ The average opportunity cost of defaulters younger than 40 years old is a positive $\$ 9,300$ (in lump sum, in 2000 dollar), while that of defaulters older than 40 years old was actually negative at $-\$ 9,480 .^{25}$ It is not surprising to have older employees defaulting to the DB plan, because they were presumably aware that making no active election would default them into the DB plan, which potentially offered greater retirement benefits. More puzzling is why so many young employees (younger than 40 years old) also defaulted to the DB plan. Next, we evaluate several potential explanations for young employees' high default rates.

A first explanation might be that some young employees face liquidity constraints, making the contributory DC plan less appealing. In fact, the average annual salary of the young defaulters was $\$ 25,000$, lower than that of the DC switchers $(\$ 27,000)$ and DB choosers $(\$ 29,000)$. If, at the extreme, the young defaulters would contribute nothing to the DC plan, and hence would be eligible for zero employee match, Panel $\mathrm{C}$ of Table 5 shows that the opportunity costs of all defaulters would be negative, indicating that the projected expected DB plan benefit would exceed the DC plan benefit. Although the liquidity constraints could help explain the default behavior of some employees, it is unlikely to explain the behavior of all young employees. Previous studies on DC plan saving found that saving rates increase with employee

age, salary, and services. ${ }^{26}$ As an employee ages, liquidity constraints relax, enabling him to save 
more for retirement. If the same employee faces high job change risk, then defaulting to the DB plan would have him forgo the upside potential of the DC plan.

Second, if the young defaulters are highly risk averse, the DB plan would be more attractive than the DC plan. For instance, defaulters might have regarded the DB plan as risk-free In this case, they would have also invested their DC accounts in risk-free assets had they switched. So the DC portfolio return would be too low for the DC benefits to catch up to the DB benchmark. Panel D of Table 5 shows that if the DC portfolio had been invested entirely in riskfree assets, earning a 4 percent annual return, the opportunity cost for the DB defaulters would be negative (with a 4 percent discount rate). Of course, the risk aversion argument might explain some defaulters' choices, but it is unlikely that it was binding to all of them. One reason is that the "risk-free" feature of the DB plan is a misperception. Although this DB plan is "free" of default risk (the probability of this firm going bankrupt is very small), the employer may still shut down the DB plan or change the benefit formula in the future. Further, there is no evidence that the young DB defaulters were more risk-averse than the young DC switchers or DB choosers. In fact, when we impute their risk aversion coefficients using the empirical technique developed by Halek (2002), the DB defaulters were less risk averse than the DC switchers.

Third, the high default rate by young employees could be a result of their not paying attention. Previous studies have found that many young employees are not very interested in retirement saving, but the older they become, the more they are involved. Accordingly, one explanation for the default behavior of some young employees could be that they did not pay attention to the choice, or the opportunity cost was not high enough to arouse their interest. Lacking individual interviews or surveys, we cannot judge the importance of inattention. 
Fourth, procrastination could also be a potential explanation for young employees' high default rate. Several analysts have found that automatic enrollment has a powerful effect on 401(k) saving behavior. In particular, Madrain and Shea (2001) and Choi et al. (2004) report that younger employees, women, and employees with shorter tenure and lower income are more likely to procrastinate, by retaining both the default contribution rate and the default allocation. If young employees tend to procrastinate more than older ones, having the DB be the default may explain why so many DB defaulters were young.

\subsection{Saving by Switched Employees}

Employees who switched to the DC plan faced two key decisions: how much to contribute to the plan, and how to allocate funds across the available investment options. Both decisions can have a profound impact on accumulated plan balances at the time of retirement, and hence they can greatly influence retiree income. Therefore we next describe how we analyze the links between DC plan contributions and employee characteristics.

Prior studies have concluded that employees' DC plan contribution rates tend to increase with age, for any given salary group. ${ }^{27}$ Two explanations have been provided for this phenomenon. First, some employees seek to smooth consumption over the life-cycle. Younger employees save less because of school expenses, house loans, and the expenses of raising a family. In contrast, older employees tend to have lower financial burdens. Second, many individuals find it difficult to make long-term plans. Munnell, Sunden, and Taylor (2000) support this theory, reporting that shorter planning horizons reduced participant contribution rates. Several empirical studies also find a positive link between age and DC plan contribution rates (Clark and Schieber, 1998; Papke, 2003; Huberman, Iyengar, and Jiang 2004). Consequently, we 
predict that age is positively associated with contribution rates. Salary is also an important determinant of retirement savings; some low earners might face liquidity constraints, making saving less likely (Goodfellow and Schieber, 1997; Clark and Schieber, 1998; Huberman, Iyengar, and Jiang 2003). Therefore we hypothesize a positive link between salary levels and contribution rates. More years of service and higher education can help employees realize the importance of retirement saving; therefore, these two also would be expected to correlate positively with DC contribution rates. It is not a clear priori how SRA savings should affect DC contribution rates. On one hand, an employee with SRA saving might simply have a higher marginal saving rate, and therefore he would be more likely to have greater DC contributions. On the other hand, SRA saving might reduce interest in the DC plan if the employee regarded his retirement saving as sufficient. Which factor dominates is an empirical question to be explored below. We also hypothesize that there may be peer effects, so that one's bargaining unit could influence employee DC saving decisions.

Because of the regulation of the IRS tax code and the employer's restriction, employee combined total annual contributions under the DC plan and the SRA generally cannot exceed the lesser of $\$ 10,500$ or 20 percent of salary. Hence, employees are capped regarding their contribution capability. In our dataset, few employees were capped by $\$ 10,500$, so we mainly focus on the 20 percent cap. Conditional on participation, the empirical model linking these variables is as following:

ContributionRate $_{i}= \begin{cases}\theta_{0}+\theta_{1} \cdot \text { DemographicFactors }_{i}+\theta_{1} \cdot \text { EconomicFactors }_{i}+e_{4} & \text { if DCR } \\ 20 \% & \text { if } \text { DCR }^{*}>20 \%\end{cases}$ where $\mathrm{DCR}^{*}$ is the desired contribution rate. Both OLS and tobit regression are employed to estimate the results. 
Switched employees' pre-tax contribution rates to the DC plan and SRA averaged 6 percent of their base salary. If we also take into account the employer basic and matching contributions, the total contribution rate averaged 12.6 percent. Figure 5 shows the distribution of employee pre-tax contribution rates. Only around 3 percent of switchers contributed nothing to the DC account, making them eligible for only the employer's basic contribution; 28 percent of the switchers obtained some employer match contribution but did not exhaust the 5 percent employer match cap. The contribution rates of a large number of the switched employees -42 percent - clustered at 5 percent, the employer match cap. This last result is consistent with Kusko, and Wilcox (1998), and Choi et al. (2002), showing the importance of the employer's match cap. The remaining 27 percent of employees saved more than 5 percent of salary. Figure 5 here

Table 6 shows how employee characteristics are associated with employee pre-tax saving, exclusive of the employer's basic and match contributions. Consistent with Clark and Schieber (1998) and Papke (2003), we find that age is positively correlated with employee contribution rates; older employees apparently care more about retirement savings and tend to contribute more than younger employees. The link between salary and contribution rate is positively significant, suggesting that high-income employees save more than low-income employees, consistent with previous studies (Goodfellow and Schieber, 1997; Clark and Schieber, 1998; Huberman, Iyengar, and Jiang 2003). In our empirical results, service, sex, and education level do not affect employee DC plan savings. We do find ethnicity matters: African Americans tend to save less than Whites, while other ethnicities saved more (including AsianAmericans and Native Americans and Hispanics). We also find that employees with an SRA 
account and more accrued DB benefits before the switch tended to save more, meaning that employees with higher saving propensity in one setting also save more in other settings. Table 6 here

\subsection{Employer Contribution Expenses}

After analyzing employee plan choices as well as the saving rates of the switchers, one might wonder how employee behavior influenced the employer's total expenses. ${ }^{28} \mathrm{We}$ focus here only on the impact of switched employees, since there is no predicted change in benefit expenses as a result of those who remained in the DB plan. To see whether the employer ended up paying more or less, we compare the present value of anticipated DB expenses had no switch occurred with those given the switch. As a benchmark case, we first estimate a conservative expense measure, assuming that all switched employees remained with the employer until retirement. In that case, the expense due to a switcher equals the expense of what the employer would have paid if the worker had remained in the DB plan: this is the present value of his DB benefit:

$$
\text { Expense }_{D B}=\frac{1}{(1+r)^{65-a_{i}}} \sum_{i} 1.25 \% \cdot \frac{1}{5}\left(\sum_{j=T-5}^{T-1} \text { Salary }_{i a_{i}}(1+w)^{j-a_{i}}\right) \cdot \text { ServiceYears }_{i T} \cdot A F_{65}
$$

where $i$ represents the $i$ th participant; $a_{i}$ is the worker's current age; $\mathrm{r}$ is the discount rate set at 7 percent; $\mathrm{T}$ is the retirement age set at $65 ; w$ is the expected wage growth rate of 3 percent; and ServiceYear $_{i T}$ is the employee $i$ 's tenure as of age $T$. The Annuity Factor at age $65, A F_{65}$, is calculated as above.

The DC expense of a switched employee is represented by the present value of the DC plan basic and match contributions, plus his accrued DB benefits: 
Expense $_{D C}=\sum_{i}\left(\sum_{j=a_{i}}^{T-1} \frac{\left(B C_{i j}+M C_{i j}\right) \cdot \text { Salary }_{i a_{i}} \cdot(1+w)^{j-a_{i}}}{(1+r)^{j-a_{i}}}+\frac{1}{(1+r)^{65-a_{i}}} \cdot D B_{-}\right.$Accrued $\left._{a_{i}} \cdot A F_{65}\right)$.

where $\mathrm{BC}_{i j}$ and $\mathrm{MC}_{i j}$ are the basic contribution and match contribution for participant $\mathrm{i}$ at his age $\mathrm{j}$, and $D B_{-}$Accrued $_{a_{i}}$ is the participant $i$ 's accrued DB benefit at his current age $a_{i}$.

By comparing Expense ${ }_{D B}$ with Expense ${ }_{D C}$, we can ascertain the employer's expenses from the DB and DC plans. Since not all employees would have actually remained at the firm until retirement, we also provide expense saving estimates that take into account non-zero turnover rates.

To explore the most expensive case, we first assume every employee would have stayed until retirement. Here, projected expenses are discounted to (2000 dollar) using a discount rate of 7 percent, consistent with the plan sponsor's assumptions. The results first illustrate projected changes in employer expenses assuming that (a) all switched employees contributed at least 5 percent of pay, to get the full employer match, and (b) turnover rates were zero. As shown in Table 7, assuming no turnover, the average projected DB plan expense per employee was $\$ 49,160$, and the per employee projected DC plan expense was quite close, $\$ 48,750$. Given actual DC switch patterns and contribution rates, however, however, the average expense of each employee was lower, at $\$ 46,210$, because one-fifth of the employees contributed less than 5 percent. When these employer expenses are summed up to calculate total expenses, we find that the total DB expense for the 1,610 employees who switched would have been a projected $\$ 79$ million dollars (171 percent of annual salary), in contrast to the projected $\$ 78.5$ million (169 percent of annual salary) assuming all employees took a full match, or \$74.4 million (161 percent of annual salary) based on actual employee contributions and no turnover. Therefore, the employer's benefit expenses would have been projected to fall if half of its eligible workforce 
switched to the DC plan and no one left before retirement. Allowing for turnover, the changes in benefit expenses were lower, since the employer has no obligation to make contributions for terminated employees. In this second case, the present value of the DB expense would have been $\$ 52.3$ million (113 percent of annual salary), very close to actual DC contributions of $\$ 52.8$ million (114 percent of annual salary), but lower than the case of a 5 percent match for everybody of \$55.2 million (119 percent of annual salary). In other words, given the actual behavior of employees who switched, there was virtually no change in employer total pension expenses after the switch.

Table 7 here

\section{Conclusions}

This paper employs a unique dataset to explore employee decisions to switch from a DB to a DC plan, the effect of default options, and the saving behavior of employees who switched into the DC plan. Our research helps understand how employees made one of their most important financial decisions, choosing a proper retirement plan, and how the different features of the DB and DC plans influenced employee choices. The analysis shows that younger, female, and higher-income workers as well as those with less service were more likely to choose a DC plan. Previous benefits also influenced plan choices: employees with lower accrued DB benefits or some previous DC savings were more likely to choose the DC plan. After incorporating positive turnover rates into an internal rate of return calculation, we find that employees with lower internal returns were more likely to choose the DC plan. This means that an employee chose a DC plan when he expected that it would be easy for him to meet or exceed the DB plan projected benefit. 
We also find that the default option can have an important impact on retirement choices. Surprisingly, about half of young employees who could potentially benefit more from the DC plan defaulted to the DB plan, and the DB defaulters were more similar to the DC switchers than the DB choosers. According to the employer's calculation, altogether the defaulted employees with positive opportunity costs gave up $\$ 7 \mathrm{M}$, or 37 percent of their annual salary.

For those who switched into the DC plan, the 5 percent plan match cap strongly affected DC plan saving rates: more than 40 percent of them saved at exactly 5 percent, and only 30 percent contributed more than 5 percent of salary. Older employees and employees with higher incomes tended to have higher contribution rates. The DC participants with an SRA account before the switch tended to save more, meaning that employees with a higher saving propensity in one form consistently save more for retirement in another form. We also find saving differences among different ethnicities: African-Americans saved less than Whites, but other ethnicities (Asian-Americans, Native-Americans, and Hispanics) saved more than Whites.

Several policy implications flow from this paper. If a Social Security reform allowed workers to redirect some of their payroll tax to an individual account, our findings suggest that the employee's characteristics, including age, salary, service, sex, and ethnicity, will have an impact on his probability of setting up an account. Moreover, having had past experience with a DC plan also influences the probability of adopting such an account. Policymakers should also contemplate what the default options, if any, should be to realize particular policy objectives. If the policy objective were to encourage young workers to set up individual accounts, the default should be the new individual account instead of the old DB plan. Another implication pertains to employee education. We believe that the high switch rate of 50 percent at this employer was partly due to market timing, but it was also the result of extensive employer communication 
about plan features and projected benefits. Consequently, employee education appears to be very important in retirement saving

In future work, we hope to evaluate how the switched employees allocated their retirement assets, and whether saving rates and asset allocation changed over time. Another interesting question is whether actual DC plan payouts proved to be higher or lower than the projected DB benefits forecasted at the switch date. We will also calculate projected DC benefits based on actual rather than hypothetical contribution rates and asset allocations, to evaluate whether switchers' DC benefits based on actual portfolios will exceed projected DB benefits at the time of the policy change. 


\section{References}

Bodie, Zvi, Alan J. Marcus, and Rober C. Merton, 1988. "Defined Benefit versus Defined Contribution Pension Plans: What Are the Real Trade-offs?" In Pensions in the U.S. Economy, edited by Zvi Bodie, John Shoven, and David Wise. Chicago, IL: University of Chicago Press: 139-162.

Brown, Kerry, Gerry Gallery, Natalie Gallery, and Ross Guest, 2004. "Employees' Choice of Superannuation Plan: Effects of Risk Transfer Costs", The Journal of Industrial Relations, Vol. 46(1): 1-20.

Childs, Paul D., Douglas Fore, Steven H. Ott, and Claude C. Lilly III, 2002. "Defined Benefit vs. Defined Contribution? Deterring the Optional Benefit Plan Choice Using a Real Options Framework", TIAA-CREF Institute Working Paper Series 9-060102.

Choi, James J., David Laibson, and Brigitte C. Madrian, 2004 (a). Plan Design and 401(k) Savings Outcomes, National Tax Journal, Vol. 57(2): 275-298.

Choi, James, David Laibson, Brigitte Madrian, and Andrew Metrick, 2004 (b). "For Better or For Worse: Default Effects and 401(k) Savings Behavior.” Forthcoming in Perspectives in the Economics of Aging, edited by David A. Wise. Chicago, IL: University of Chicago Press, 2004.

Choi, James J., David Laibson, Brigitte Madrian, and Andrew Metrick, 2002. “Defined Contribution Pensions: Plan Rules, Participant Choices, and the Path of Least Resistance.” In Tax Policy and the Economy, Volume 16, edited by James Poterba. Cambridge, MA: MIT Press, 2002: 67-113.

Clark, Robert L., Linda S. Ghent, and Ann A. McDermed, 2003, "Pension Plan Choice among University Faculty", working paper of North Carolina State University. 
Clark, Robert, Loretta Harper, and M. Melinda Pitts, 1997. "Faculty Pension Choices in a Public Institution: Defined Benefit and Defined Contribution Plans", TIAA-CREF Institute Research Dialogue, Issue 50.

Clark, Robert L. and Sylvester Schieber, 1998. "Factors Affecting Participation Levels in 401(k) Plans.” In Living with Defined Contribution Plans: Remaking Responsibility for Retirement, edited by Olivia Mitchell and Sylvester J. Schieber. Philadelphia, PA: University of Pennsylvania Press, 1998: 69-97

Cogan, John F., and Olivia S. Mitchell, 2003. "Perspectives from the President's Commission on Social Security Reform”, Journal of Economic Perspectives, Vol. 17 (2): 149-172.

Duflo, Esther, and Emmanuel Saez, 2002. "Participation and Investment Decisions in a Retirement Plan: The Influence of Colleagues' Choices", Journal of Public Economics, Vol.85: 121-148.

Engelhardt, Gary, and Anil Kumar, 2004. "Employer Match and 401(k) Saving: Evidence from the Health and Retirement Study", Center for Retirement Research at Boston College, WP 2004-18.

Feinberg, Phyllis, 2004. “Brighter Skies in Forecast for Florida’s 401(a) Plan”, Pension \& Investments, Vol. 32(9): 4-6.

Fore, Douglas, 2001. "Going Private in the Public Sector: The Transition form Defined Benefit to Defined Contribution Pension Plans”. Chapter 12 of Pension in the Public Sector, edited by Olivia S. Mitchell and Edwin C. Hustead. University of Pennsylvania Press, Philadelphia, 288-312.

Goodfellow, Gordon P., and Sylvester J. Schieber (1997). "Investment of Assets in Self-Directed Retirement Plans", In Positioning Pensions for the Twenty-First Century, edited by 
Michael S. Gordon, Olivia S. Mitchell and Marc M. Twinney. Philadelphia, PA: University of Pennsylvania Press, 1997: 67-90.

Halek, Martin, 2002, “Essays in Insurance and Risk Management”, Ph.D. Dissertation, Insurance and Risk Management Department, University of Pennsylvania.

Holden, Sarah, and Jack VanDerhei, 2001. "Contribution Behavior of 401(k) Plan Participants", EBRI Issue Brief, October 2001.

Huberman, Gur, Sheena Iyengar, and Wei Jiang, 2004. "Defined Contribution Pension Plans: Determinants of Participation and Contribution Rates”. Columbia Business School Working Paper.

Kahneman, Daniel \& Knetsch, Jack L \& Thaler, Richard H, 1991. "The Endowment Effect, Loss Aversion, and Status Quo Bias: Anomalies," Journal of Economic Perspectives, Vol. 5(1): 193-206.

Kusko, Andrea, James Poterba and David Wilcox. 1998. "Employee Decisions with Respect to 401(k) Plans.” In Living with Defined Contribution Pensions: Remaking Responsibility for Retirement, Edited by Olivia Mitchell and Sylvester Schieber. Philadelphia, PA: University of Pennsylvania Press: 98-112.

Lachance, Marie-Eve, Olivia S. Mitchell, and Kent Smetters, 2003. “Guaranteeing Defined Contribution Pensions: The Option to Buy Back a Defined Benefit Promise", Journal of Risk \& Insurance, Vol. 70: 1-16.

Madrian, Brigitte C., and Dennis F. Shea, 2001. “The Power of Suggestion: Inertia in 401(k) Participation and Savings Behavior." Quarterly Journal of Economics, Vol. 116(4): 11491525. 
McCarthy, David, 2003. "A Life-Cycle Analysis of Defined Benefit Pension Plans”, Journal of Pension Economics and Finance, Vol. 2(2): 99-126.

Mitchell, Olivia S., 2000. "Developments in Pensions", Handbook of Insurance, edited by Georges Dionne. Boston/Dordrecht/London: Kluwer Academic Publishers, 2000: 873-899.

Munnell, Alicia H., Annida Sunden, and Catherine Taylor, 2000. "What Determines 401(k) Participation and Contributions?" CRR Working Paper 2000-12. Center for Retirement Research, Boston College.

Papke, Leslie, 2004. "Pension Plan Choice in the Public Sector: The Case of Michigan State Employees", National Tax Journal, Vol. 57(2), Part 1: 329-339.

Papke, Leslie, 2003. "Individual Financial Decisions in Retirement Saving Plans: The Role of Participant-Direction”, Journal of Public Economics, Vol. 88: 39-61.

Rappaport, Anna M., 2004. "Exploding the Myth That Employees Always Prefer DC Plans", $A$ Mercer Perspective on Retirement, Mercer Human Resource Consulting, http://www.mercerhr.com/summary.jhtml/dynamic/idContent/1138485, May 2004.

Trager, Kenneth, James Francis, and Kevin SigRist, 2001. "Florida's Public Pension Reform Debate", In Pension in the Public Sector, edited by Olivia S. Mitchell and Edwin C. Hustead. Phliadelphia, PA: University of Pennsylvania Press, 2001: 288-312.

Tversky, Amos, and Daniel Kahneman, 1991. "Loss Aversion in Riskless Choice: A ReferenceDependent Model," The Quarterly Journal of Economics, Vol. 106 (4): 1039-61. 
Table 1. Comparison of DB and DC Plan Characteristics.

\begin{tabular}{|l|l|l|l|}
\hline & \multicolumn{1}{|c|}{ DB Plan } & \multicolumn{1}{c|}{ DC Plan } & Dominant Plan \\
\hline Investment Choices & $\begin{array}{l}\text { Participants have no control } \\
\text { over the investment of pension } \\
\text { money. }\end{array}$ & $\begin{array}{l}\text { Usually participants make } \\
\text { their investment decisions. }\end{array}$ & DC \\
\hline Investment Risk & $\begin{array}{l}\text { Participants do not need to } \\
\text { bear investment risk. }\end{array}$ & $\begin{array}{l}\text { Participants have to bear all } \\
\text { investment risk. }\end{array}$ & DB \\
\hline Investment Returns & $\begin{array}{l}\text { Participants can only collect } \\
\text { the benefits defined in the DB } \\
\text { formula even if the investment } \\
\text { has favorable returns. }\end{array}$ & $\begin{array}{l}\text { Participants are entitled to all } \\
\text { investment returns. }\end{array}$ & Not clear ${ }^{2}$ \\
\hline $\begin{array}{l}\text { Termination and } \\
\text { Portability }\end{array}$ & $\begin{array}{l}\text { Participants leaving their job } \\
\text { forfeit future indexation of } \\
\text { benefits already accrued. }\end{array}$ & $\begin{array}{l}\text { Participants could rollover and } \\
\text { keep investing investment } \\
\text { savings. }\end{array}$ & DC \\
\hline Incentives & $\begin{array}{l}\text { Participants have greater } \\
\text { incentive to sustain a high } \\
\text { level of effort over the entire } \\
\text { career in order to achieve a } \\
\text { high career-end salary. }\end{array}$ & $\begin{array}{l}\text { Participants have less } \\
\text { incentive over their entire life } \\
\text { than in the DB plan since their } \\
\text { DC benefits depend upon the } \\
\text { wage trajectory over their } \\
\text { entire life }\end{array}$ & DB \\
\hline Wage-Path Risk & $\begin{array}{l}\text { Benefits tied to wage used in } \\
\text { the formula, mostly the final } \\
\text { wage. }\end{array}$ & $\begin{array}{l}\text { Benefits tied to career average } \\
\text { earnings. }\end{array}$ & Not clear ${ }^{3}$ \\
\hline Life Annuity & $\begin{array}{l}\text { Usually offers life annuity } \\
\text { with favorable mortality rates }\end{array}$ & $\begin{array}{l}\text { Most DC plans' distribution is } \\
\text { lump sum. Participants might } \\
\text { face unfavorable mortality rate } \\
\text { when purchasing annuity in } \\
\text { market due to adverse } \\
\text { selection problem. }\end{array}$ & DB \\
\hline
\end{tabular}

Source: Author's summary extending Bodie, Marcus, and Merton (1988).

Notes:

1. Papke (2003) mentioned that 82 percent of 34 million participants in 401(k) plans had some control over their investments in 1997.

2. Since DC participants bear investment risk, participants have the potential to have DC benefits exceed DB if they make correct choices. But it is also possible that DC benefits could be lower than DB benefit if the participants make wrong investment decisions.

3. On one hand, DB benefits tied to final wage could provide employees with a type of incomemaintained insurance not available to those in the DC plan. On the other hand, if wage paths are unpredictable, it might be very risky to tie one's pension benefits to the final wage. 
Table 2. Sample Economic and Demographic Characteristics

\begin{tabular}{|c|c|c|c|c|c|c|}
\hline Variable & & Unit & $\begin{array}{l}\text { Sample } \\
\text { Average }\end{array}$ & $\begin{array}{c}\text { DB } \\
\text { Choosers }\end{array}$ & $\begin{array}{c}\text { DC } \\
\text { Switchers }\end{array}$ & $\begin{array}{c}\text { DB } \\
\text { Defaulters }\end{array}$ \\
\hline$(\mathrm{DC}-\mathrm{DB})_{65}$ & $\begin{array}{l}\text { Benefit difference between } \\
\text { DC and DB plan if } \\
\text { employee stays with } \\
\text { employer until } 65\end{array}$ & \$K & 3.29 & -1.48 & 2.68 & 5.82 \\
\hline $\begin{array}{l}\text { IRR with } \\
\text { Turnover }\end{array}$ & $\begin{array}{l}\text { Internal Rate of Return with } \\
\text { turnover rate }\end{array}$ & $\%$ & 0.09 & 0.21 & 0.07 & 0.10 \\
\hline SRA99 & $\begin{array}{l}\text { Other DC savings (pre } \\
2000)\end{array}$ & $0 / 1$ & 0.18 & 0.29 & 0.25 & 0.08 \\
\hline Risk Averse & Risk aversion & Num & 1.43 & 1.32 & 1.53 & 1.44 \\
\hline Accrued DB & $\begin{array}{l}\text { Accrued DB benefit as of } \\
2000\end{array}$ & \$K & 3.06 & 6.05 & 2.92 & 2.21 \\
\hline Age & Age & Num & 41 & 53 & 40 & 38 \\
\hline Salary & Salary & \$K & 27.7 & 31.3 & 28.7 & 26.1 \\
\hline Service & Year of service & Num & 9 & 16 & 8 & 7 \\
\hline Male & Male & $0 / 1$ & 0.41 & 0.36 & 0.36 & 0.45 \\
\hline Degree & At least college degree & $0 / 1$ & 0.25 & 0.20 & 0.28 & 0.26 \\
\hline eth AfricanAm & African American & $0 / 1$ & 0.35 & 0.33 & 0.32 & 0.38 \\
\hline eth_Other & $\begin{array}{l}\text { Other ethnicity (Hispanic, } \\
\text { Asian-American, and Native } \\
\text { American) }\end{array}$ & $0 / 1$ & 0.05 & 0.01 & 0.06 & 0.05 \\
\hline Union & Unionized & $0 / 1$ & 0.28 & 0.38 & 0.23 & 0.29 \\
\hline Vested & Vested & $0 / 1$ & 0.57 & 0.88 & 0.57 & 0.43 \\
\hline Observations & & & 3474 & 220 & 1701 & 1169 \\
\hline
\end{tabular}


Table 3. Determinants of Employee Choice between DB and DC Plans

(Dependent Variable: 1=DC, $0=\mathrm{DB}$ )

(1)

(2)

(3)

(4)

\section{Economic Factors}

(DC-DB)65

IRR

Salary

Accrued DB

SRA99

\section{Demographic Factors}

Age

Service

Male

Degree

eth_AfricanAm

eth_other

Union

Vested

\section{Observations}

R-squared

Note: 1.Robust standard errors in brackets. ${ }^{*}$ significant at 5 percent; $* *$ significant at 1 percen
$-0.006^{* *}$

[0.001]

$-1.191 * *$

[0.273]

$0.009 * *$

[0.002]

$-0.016^{* *}$

[0.005]

$0.211 * * \quad 0.210^{* *}$

[0.022]

[0.022]

$0.178^{* *}$

$0.235^{* *}$

[0.023]

[0.023]

$\begin{array}{cc}-0.072 * * & -0.087 * * \\ {[0.024]} & {[0.025]} \\ 0.034 & -0.018 \\ {[0.025]} & {[0.025]} \\ -0.118^{* *} & -0.121^{* *} \\ {[0.021]} & {[0.022]} \\ -0.037 & -0.068 \\ {[0.043]} & {[0.044]} \\ -0.150^{* *} & -0.124^{* *} \\ {[0.023]} & {[0.024]}\end{array}$

[0.027]

$-0.005 * * \quad-0.004 * *$

[0.001] [0.001]

$-0.103 * *$

[0.024]

$-0.016$

[0.025]

$-0.083 * *$

[0.022]

$-0.047$

[0.043]

$[0.023]$

$-0.134 * *$

[0.024]

3039

3061

3037

0.11

2. Missing value dummies included, but not reported here.

(4) 
Table 4. Differences between DB Defaulters and DB Choosers

(Dependent Variable: 1=DB Defaulter, $0=$ DB Chooser)

(1)

(2)

(3)

(4)

Economic Factors

(DC-DB) 65

$0.014 * *$

IRR

[0.001]

IRR

Salary

$-0.002$

Accrued DB

[0.001]

SRA99

$\begin{array}{ll}-0.088 * * & -0.067 * \\ {[0.031]} & {[0.029]}\end{array}$

$-0.115 * *$

$-0.171 * *$

Demographic Factors

Age

$-0.006^{* *} \quad-0.006^{* *}$

Service

[0.001]

[0.001]

$-0.005^{* *}$

Male

$0.047^{*}$

$0.050 *$

[0.032]

$-0.075^{*}$

[0.035]

[0.020]

Degree

0.007

[0.019]

$0.051 * *$

$0.081 * *$

[0.021]

$-0.012$

[0.019]

[0.023]

eth_AfricanAm

$0.057^{* *}$

[0.021]

$-0.007$

$0.044^{*}$

[0.017]

$0.055^{* *}$

[0.021]

[0.021]

eth_other

$0.080 * *$

[0.016]

$0.065 * *$

$0.072 * *$

[0.016]

$0.077 * *$

[0.016]

[0.018]

[0.014]

$0.080 * *$

$0.109 * *$

Union

0.002

$-0.001$

[0.016]

[0.015]

[0.018]

[0.018]

0.002

$-0.032$

Vested

$-0.03$

[0.023]

\begin{tabular}{lcccc} 
Observations & 1389 & 1345 & 1376 & 1345 \\
R-squared & 0.27 & 0.29 & 0.23 & 0.14 \\
\hline
\end{tabular}

Note: 1.Robust standard errors in brackets. ${ }^{*}$ significant at 5 percent; ${ }^{* *}$ significant at 1 percent 2. Missing value dummies included, but not reported here. 
Table 5. Opportunity Cost of DB Defaulters (Discounted to 2000 dollar) OpportunityCost $_{i}=P V\left(\right.$ projected_DCBenefits $\left._{i}\right)-P V\left(\right.$ projected_DBBenefits $\left._{i}\right)$

\# of Obs. Average (K\$) Total $(\mathrm{M} \$) \quad \%$ of Annual Salary

\section{Panel A: Base Case ${ }^{1}$}

\begin{tabular}{crrrr} 
All Defaulters & 1142 & 2.7 & 3.1 & $9 \%$ \\
\hline $\begin{array}{c}\text { Defaulters with Positive } \\
\text { Opportunity Costs }\end{array}$ & 730 & 9.3 & 6.8 & $37 \%$ \\
Age 20-30 & 412 & 11.4 & 4.7 & $48 \%$ \\
Age 31-40 & 273 & 7.3 & 2 & $28 \%$ \\
Age 41-50 & 45 & 2.6 & 0.1 & $9 \%$ \\
Age 51+ & 0 & 0 & 0 & \\
\hline
\end{tabular}

\section{Panel B: Including Expected Turnover}

\begin{tabular}{crrrr} 
All Defaulters & 1142 & 3.3 & 3.8 & $13 \%$ \\
\hline $\begin{array}{l}\text { Defaulters with Positive } \\
\text { Opportunity Costs }\end{array}$ & 791 & 8.4 & 6.6 & $34 \%$ \\
Age 20-30 & 412 & 9.7 & 4 & $41 \%$ \\
Age 31-40 & 300 & 8 & 2.4 & $31 \%$ \\
Age 41-50 & 79 & 3.2 & 0.3 & $13 \%$ \\
Age 51+ & 0 & 0 & 0 & \\
\hline
\end{tabular}

Panel C: Including Expected Turnover, and 0 Employer Match (Liquidity Constraints)

\begin{tabular}{lcccc} 
All Defaulters & 1142 & -27.21 & -31.07 & $-104 \%$ \\
\hline Defaulters with Positive & & & & \\
Opportunity Costs & 0 & 0 & 0 & \\
\hline
\end{tabular}

Panel D: Including Expected Turnover, and 4\% Investment Return and Discount Rate (Highly Risk Averse)

\begin{tabular}{lrrrr} 
All Defaulters & 1142 & -21.18 & -8.9 & $-81.3 \%$ \\
\hline Defaulters with Positive & & & & \\
Opportunity Costs & 0 & 0 & 0 & \\
\hline
\end{tabular}

Note: 1 . Base case assumptions: match contribution $=5 \%$, investment return $=7 \%$, discount rate $=7 \%$, wage growth $=3 \%$, and no turnover 


\section{Table 6. Effects of DC Switcher Characteristics on DC Plan Contributions}

OLS

\begin{tabular}{lcc}
\hline Economic Factors & & \\
Salary & $0.036^{*}$ & $0.036^{*}$ \\
& {$[0.015]$} & {$[0.016]$} \\
SRA99 & $0.031^{* *}$ & $0.031^{* *}$ \\
& {$[0.002]$} & {$[0.002]$} \\
Demographic Factors & & \\
Age & $0.071^{* *}$ & $0.073^{* *}$ \\
& {$[0.012]$} & {$[0.011]$} \\
Male & 0.003 & 0.003 \\
& {$[0.002]$} & {$[0.002]$} \\
Degree & 0.245 & 0.256 \\
& {$[0.239]$} & {$[0.232]$} \\
Service & -0.021 & -0.021 \\
& {$[0.018]$} & {$[0.016]$} \\
eth_AfricanAm & $-0.008^{* *}$ & $-0.008^{* *}$ \\
& {$[0.002]$} & {$[0.002]$} \\
eth_Other & $0.012^{*}$ & $0.012^{* *}$ \\
& {$[0.005]$} & {$[0.004]$} \\
Union & -0.004 & -0.004 \\
& {$[0.004]$} & {$[0.004]$} \\
\hline Observations & 1606 & 1606 \\
R-squared & 0.22 & $0.04^{*}$ \\
\hline Note: 1. Robust standard errors in brackets. ${ }^{*}$ significant at 5 percent; $* *$ significant at 1 percent \\
3. Pseudo R-squared from Tobit analysis.
\end{tabular}


Table 7. Present Value of Employer Pension Expenses (In 2000 dollar)

\begin{tabular}{|c|c|c|c|c|c|c|}
\hline & \multicolumn{3}{|c|}{ No Turnover } & \multicolumn{3}{|c|}{ With Turnover } \\
\hline & $\begin{array}{c}\text { Per Employee } \\
(\$)\end{array}$ & $\begin{array}{l}\text { Total } \\
(\$ \mathrm{M})\end{array}$ & $\begin{array}{l}\text { \% of EE } \\
\text { Salary }\end{array}$ & $\begin{array}{c}\text { Per Employee } \\
(\$)\end{array}$ & $\begin{array}{l}\text { Total } \\
\text { (\$M) }\end{array}$ & $\begin{array}{l}\% \text { of EE } \\
\text { Salary }\end{array}$ \\
\hline $\begin{array}{l}\text { DB expense } \\
\text { DC exnense with }\end{array}$ & 49,160 & 79.14 & $171 \%$ & 32,510 & 52.35 & $113 \%$ \\
\hline $\begin{array}{l}5 \% \text { match } \\
\text { DC expense with }\end{array}$ & 48,750 & 78.49 & $169 \%$ & 34,280 & 55.19 & $119 \%$ \\
\hline actual match & 46,210 & 74.4 & $161 \%$ & 32,790 & 52.8 & $114 \%$ \\
\hline
\end{tabular}

Source: Author's calculation

Note: discount rate $=7 \%$, and wage growth $=3 \%$. 
Figure 1: Employee Plan Choices

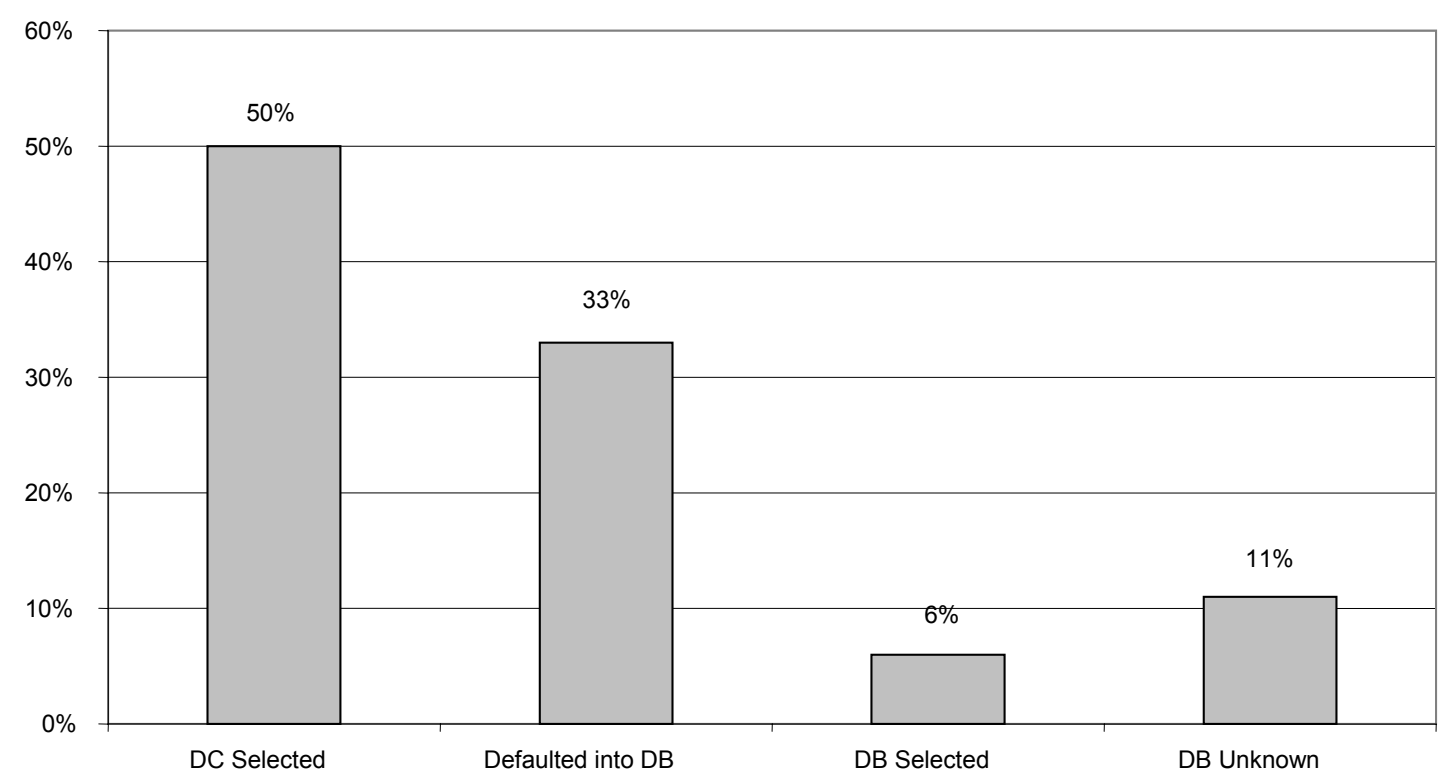

Source: Author's tabulation.

Figure 2. Employee Plan Choices by Age

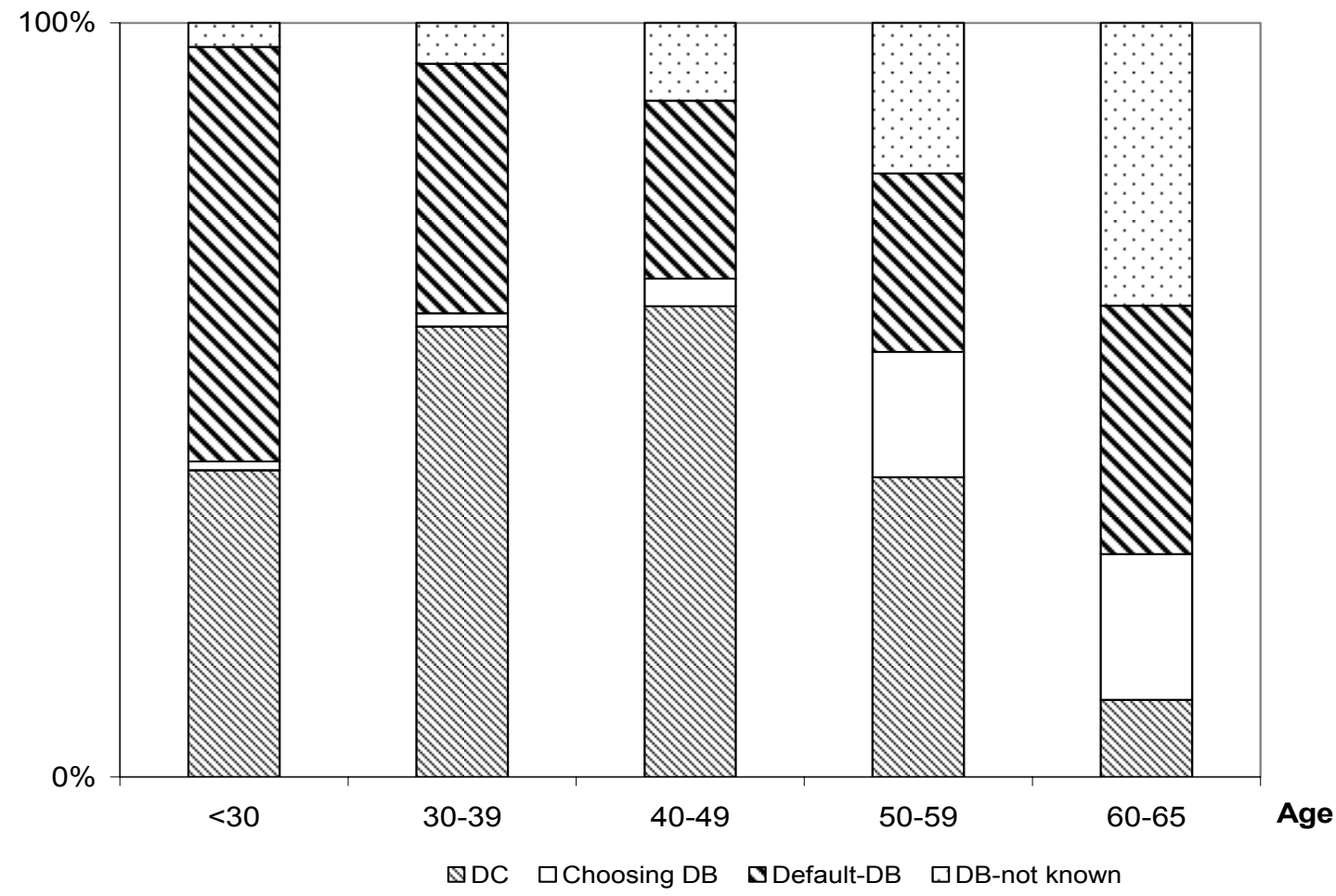

Source: Author's tabulation. 
Figure 3: Internal Rate of Return vs. Plan Choice

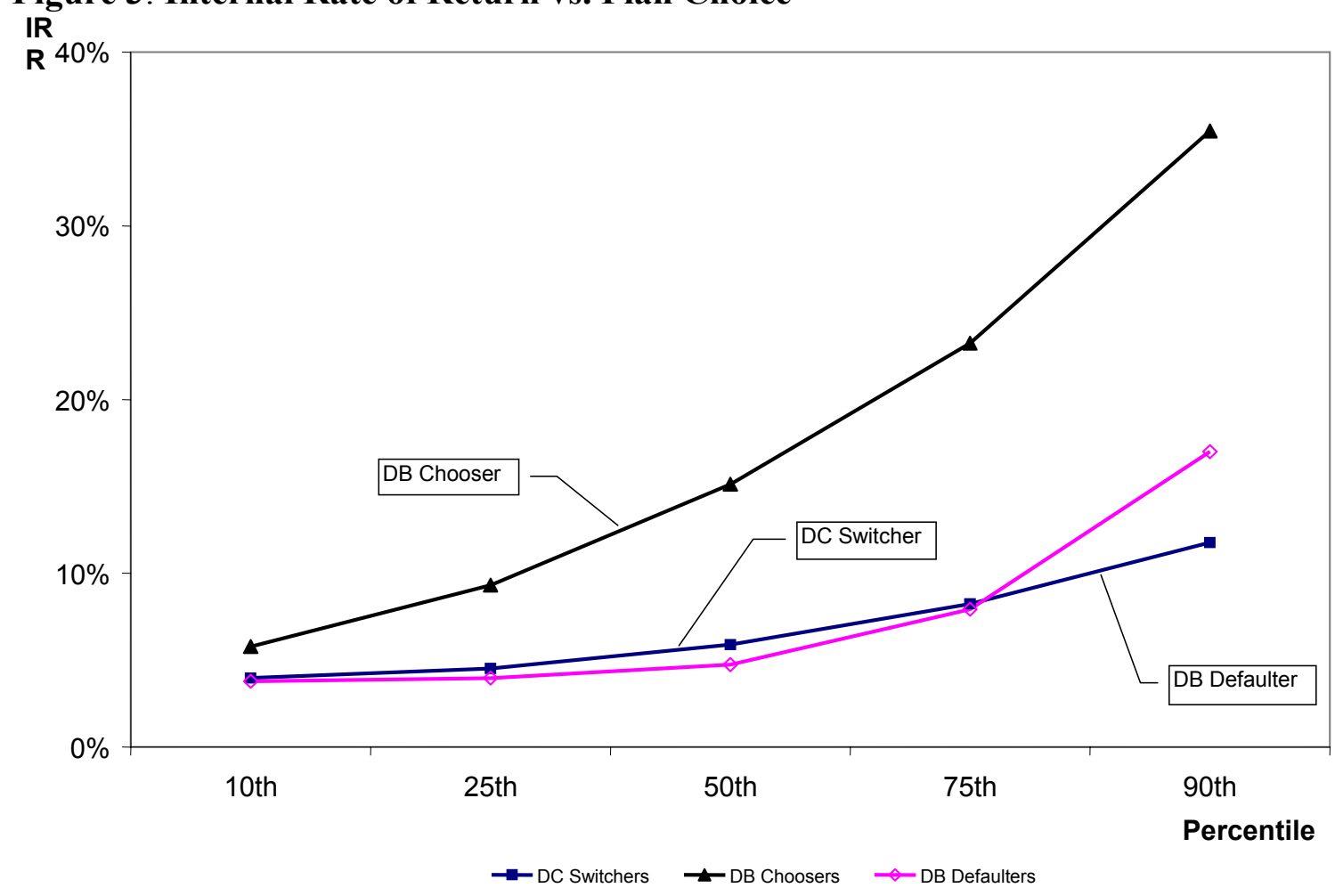

Source: Author's calculation.

Figure 4: Predicted Switch Probabilities

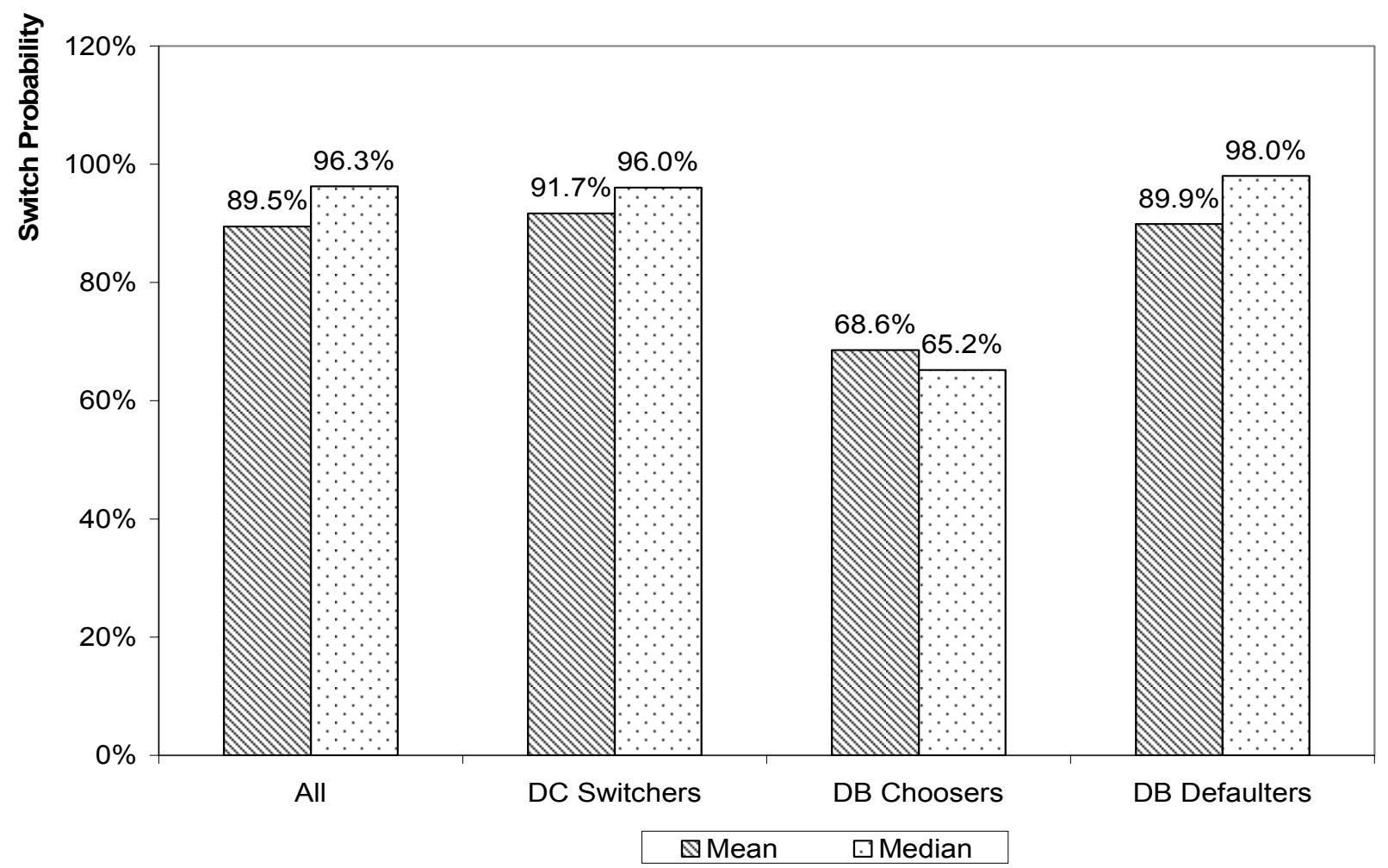

Source: Author's calculation. 
Figure 5: Distribution of DC Contribution Rates among Employees Who Switched

$\%$ of DC Participants

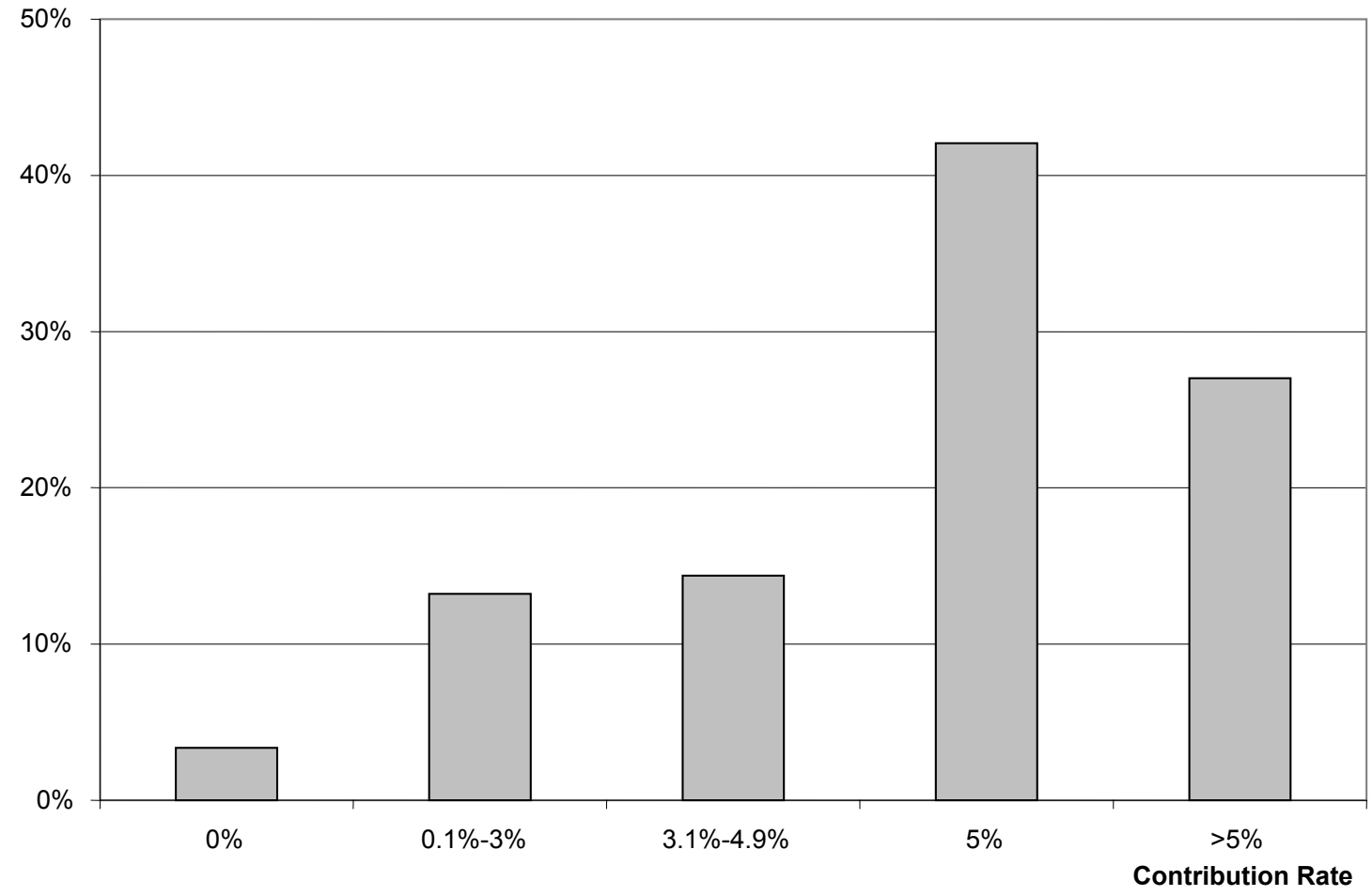

Source: Author's tabulation. 


\section{Appendix 1: The Sample Illustration of Annual Retirement Benefits}

\section{Firm Name \\ Illustration of Annual Retirement Benefits \\ $\underline{\text { Retirement DB vs. DC Plan }}$}

Prepared for:

Name

Address

$\begin{array}{rr}\text { Assumptions: } & \\ \text { Age in Calendar Year 2000: } & 31 \\ \text { Age Benefits Begin: } & 65 \\ \text { Current Annual Salary: } & \$ 24,000 \\ \text { Years of Prior DB Service: } & 1 \\ \text { Investment Rate of Return: } & 7.00 \% \\ \text { Future Salary Increase Rate: } & 3.00 \% \\ \text { Employee Contribution Rate: } & 5.00 \% \\ \text { Estimated Annual DB Benefit } & \\ \text { Payable at Age 65 (See Notes 1 and 2): \$ } & 267\end{array}$

Projected benefits shown below are based on various assumptions. Actual benefits may be higher or lower.
Annual Retirement Benefit at Age 65

Assuming Continued

Employment to Retirement

(D)

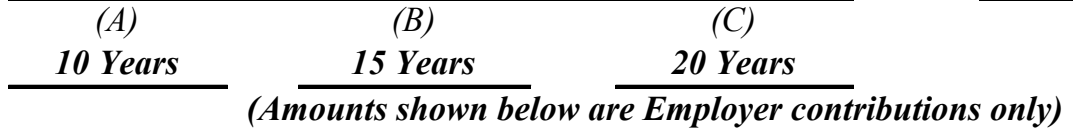

\begin{tabular}{|c|c|c|c|c|c|}
\hline Remain in $D B$ & DB Benefit (Notes $1 \&$ 2) & $\$ 4,062$ & $\$ 6,850$ & $\$ 10,422$ & $\$ 26,273$ \\
\hline \multirow[t]{4}{*}{ Join DC Plan } & Total DC + DB Benefit & $\$ 14,628$ & $\$ 20,608$ & $\$ 25,551$ & $\$ 35,289$ \\
\hline & Estimated DB Benefit (Notes $1 \& 2$ ) & $\$ 267$ & $\$ 267$ & $\$ 267$ & $\$ 267$ \\
\hline & Basic DC Benefit (Note 3) & $\$ 5,478$ & $\$ 8,136$ & $\$ 10,333$ & $\$ 14,661$ \\
\hline & Matching DC Plan (Note 4) & $\$ 8,883$ & $\$ 12,205$ & $\$ 14,951$ & $\$ 20,361$ \\
\hline
\end{tabular}

Calculation Notes: 1. 2.3.4.5.

Note: The projected benefits shown above are based on various assumptions. Actual benefits may be higher or lower. 


\section{Endnotes}

${ }^{1}$ In the United States, the number of employer-sponsored DC plans increased from 331,000 in 1979 to 674,000 in 1998 , while the number of defined benefit plans decreased from 140,000 to 56,000. Meanwhile, DC plans have enlarged their coverage from 18 million employees in 1979 to 57 million in 1998, while defined benefit DB coverage increased only slightly, from 37 million to 42 million (USDOL 2001-2002).

${ }^{2}$ See Mitchell (2000) and Fore (2001) for details.

${ }^{3}$ DC plans are attractive to employees because of individual involvement, more investment choice, immediate vesting, and portability at job change; employers also like DC plans because they are easy to communicate to employees and there is no underfunding risk.

${ }^{4}$ For instance, Bodie, Marcus, and Merton (1988), and McCarthy (2003) find that there are trade-offs between DB and DC plans, and so there is no clear dominance.

${ }^{5}$ For example, the three models suggested by the President's Commission on Social Security Reform allow employees to redirect part of their Social Security payroll tax to an individual account. See Cogan and Mitchell (2003) for details.

${ }^{6}$ In our case, since the probability of the employer going bankrupt is very small, the default risk should not be a big problem for DB participants. Also, the influence of default risk is mitigated to some extent by the benefit insurance provided by Pension Benefit Guaranty Corporation (PBGC).

${ }^{7}$ This is more likely to happen in the public sector, as in North Carolina State University (Clark, Harper, and Pitts, 1997), State Teacher's Retirement System of Ohio (http://www.strsoh.org/newmembers/3.htm), Florida (http://www.frs.state.fl.us/) after June 1, 2002, and Colorado after January 1, 2006 (http://www.copera.org). 
${ }^{8}$ This happened in both the private and public sectors; c.f. the large electronics employer and a large health care employer mentioned by Rappaport (2004), Colorado State Employee's Retirement System (Fore 2001), Florida’s Daytona Beach Community College (Trager, Francis, and SigRist, 2001), and the Michigan State Employee Retirement System (Papke, 2004).

${ }^{9}$ In a more sophisticated analysis, Lachance, Mitchell, and Smetters (2003) examined a different aspect of the Florida state plan. Not only were employees offered a chance to switch from a DB to a DC plan, but they were also granted one subsequent chance to switch back to the old plan. That study presents a simulation of the value of the option to buy back the DB benefit, but it did not link actual behavior to observed employee characteristics.

${ }^{10}$ Full-time monthly paid employees were participating in a DC plan, in which they had to contribute a specified amount of money, choose their own investment, bear the investment risk, and receive the accumulated balance.

${ }^{11}$ Employee reactions were reported in the firm's internal newsletters.

${ }^{12}$ Up to 5 percent of employee contribution went to the match plan, and entitled them to the dollar-to-dollar employer match up to 5 percent as described below. An employee's contribution above 5 percent would go to the Simplified Retirement Account, a supplementary DC-type retirement saving account offered to all employees.

${ }^{13}$ All newly hired employees meeting participation requirements after the 2000 switch date are eligible only for the DC plan.

${ }^{14}$ An additional 384 employees were in the DB plan after the switch, but the dataset did not indicate whether they selected the plan or defaulted to it. In the multinomial logit regression below in Table 3 and Table 4, those 384 employees are omitted.

${ }^{15}$ Missing values are flagged with a dummy variable and included in all regressions. 
${ }^{16}$ All the benefit amounts provided by the employer to the employee in the Personalized Illustration of Annual Retirement Benefits reflected only employer contributions, without taking into account employee contributions. The employer's computations assumed the following: an investment return of 7 percent; future annual salary increases of 3 percent; retirement at age 65 ; and employee DC contribution rates of 5 percent. The benefit differences were calculated by subtracting the DB annuity amount from the DC annuity amount, which was converted from the lump sum under the Single Life Annuity Option. To guarantee comparability between DB and DC benefits, DC benefits were assumed to be paid under the Single Life Annuity Option, which pays a benefit during the lifetime of the participant only; mortality assumptions were based on the Annuity 2000 Table (Merged Gender) with age setback 2 years. The annuity conversion interest rate was assumed at 7 percent. The difference between the projected DC and DB benefits at age 65 was equal to [Converted DC annuity ${ }_{65}+$ Accured DBannuity now $-D B^{-D n n u i t y}{ }_{65}$ ]. ${ }^{17}$ The definition and influence of Internal Rate of Return will be introduced later in this section. ${ }^{18}$ The DB plan is a non-contributory plan, and vested employees were eligible to plan benefits without contributing into the plan. In the DC plan, all employees could receive the employer's basic contribution without contributing anything, but to receive employer's dollar-for-dollar match contribution, positive employee contributions were required. Hence, lower-income employees facing possible liquidity constraints might not have extra money to make positive employee contributions, therefore forfeiting their rights to receive the employer match, which would in turn entitle them to fewer benefits in the DC plan than they would have received by remaining in the DB plan. Furthermore, the major risk in the DC plan is investment risk: if an employee invests in equities instead of in low-risk instruments such as money market funds or long-term bond funds, he may lose some of the value of his portfolio. A higher income might enable an individual to bear more risk by providing a cushion for bad returns, so we predict that, 
all else constant, the higher the employee's salary, the more likely that he would have switched to the DC plan.

${ }^{19}$ The vesting policy in our case differs from that of the Michigan State public pension plan participants (Papke, 2004). In our case, all the accrued DB benefits of vested employees are frozen if they switch to the DC plan. Non-vested employees with at least 5 years' combined service in the DB and the DC plans will vest in the frozen DB benefits accrued as of June 30, 2000. But if a non-vested employee leaves the employer before completing 5 years, he will forfeit his DB benefits. However, in Michigan's case, all the vested accrued DB benefits could be transferred to the DC plan to be indexed to future investment returns. Hence, we would predict a smaller influence of vesting in our case than in Michigan's case.

${ }^{20}$ The unreported analysis shows that the projected benefit differences calculated by assuming the employee stays with the employer for an additional 10, 15, and 20 years generates similar influences as does (DC-DB) 65 .

${ }^{21}$ Another important reason for the negative link between (DC-DB) and switch decision is, as we will show in the next section, that a large number of young employees, who potentially could benefit more from the DC plan than from the DB plan (i.e., higher value of (DC-DB) ${ }_{65}$ ), actually defaulted to the DB plan by making no active elections.

${ }^{22}$ See Tversky and Kahneman (1991) and Kahneman, Knetsch, and Thaler (1991) for details.

${ }^{23}$ In calculating the expected DC benefits, to compare with the non-contributory DB plan benefits, we only take into account the employer's basic and match contribution (at 5 percent of match cap), without any employee's contribution. However, one might say that this is still not fair, since the employer's match is conditional on the employee's positive contribution. Actually, an employee's voluntary contribution at 5 percent to get 5 percent match could be treated as redirecting the employee's other saving outside of the DB plan before switch ( 5 percent of pay) 
to the DC plan. For many employees without liquidity restrictions, contributing 5 percent of pay is rational for several reasons. First, the employer match in this case, dollar-for-dollar up to 5 percent, is relatively generous (the typical match formula in the United States is fifty-cents-perdollar up to 6 percent). For many employees, especially the young, the total amount of employee compensation, salary plus benefits, may be higher when an employee receives an employer match by contributing to the DC plan. Also, employees can get a tax benefit from retirement saving, since DC plan contributions and investment returns are tax deferred. In fact, we will see in section 3.3 that 70 percent of employees contributed no less than 5 percent, which exhausted the entire employer match.

${ }^{24}$ The age distribution of DB defaulters is significantly different from that of the DB choosers. Among the defaulters, 62 percent were younger than 40 years old, while only 12 percent of DB choosers were younger than 40 years old.

${ }^{25}$ The older employees could obtain more benefits from the DB plan partially because the backloading feature of the DB plan favors the long-tenured employees who would stay with the employer until retirement, and partially because the DC plan investment period is shorter for the old employees to accumulate a high account balance.

${ }^{26}$ See Clark and Schieber (1998), Huberman, Iyengar, and Jiang (2003, 2004), Engelhardt and Kumar (2004).

${ }^{27}$ See Holden and VanDerhei (2001) for details.

${ }^{28}$ We have no information on plan administrative cost, so our impact analysis concentrates on contribution expenses. 